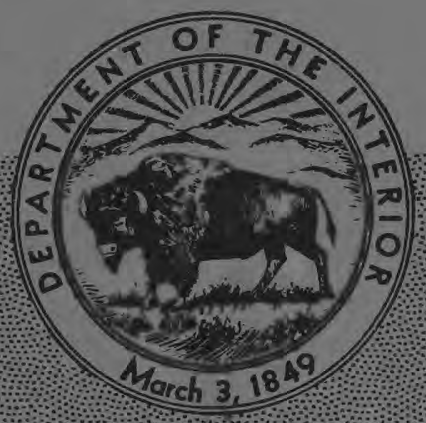

\title{
SELECTED PAPERS ON \\ URANIUM DEPOSITS IN \\ THE UNITED STATES
}




\section{UNITED STATES DEPARTMENT OF THE INTERIOR}

Oscar L. Chapman, Secretary

GEOLOGICAL SURVEY

W. E. Wrather, Director

GEOLOGICAL SURVEY CIRCULAR 220

\section{SELECTED PAPERS ON URANIUM DEPOSITS IN THE UNITED STATES}

This report concerns work done on

behalf of the U. S. Atomic Energy

Commission and is published with

the permission of the Commission

Washington, D. C., 1952

Free on application to the Geological Survey, Washington 25, D. C. 


\section{PREFACE}

The six papers included in this report were prepared in an attempt to summarize briefly and make available to the public part of the information concerning uranium deposits that is in unpublished reports of work done by the U. S. Geological Survey under the auspices, first of the Manhattan Engineer District, and later, the U. S. Atomic Energy Commission. They were prepared for oral presentation and were read at the meetings of the Rocky Mountain Section of the Geological Society of America at Rapid City, S. Dak., on April 13, 1951. They are, consequently, of limited scope. It is believed, however, that the publication of these speeches in their present form will assist persons currently engaged in the search for and study of uranium deposits. Abstracts of the papers were published by the Geological Society of America in 1951 (Bull., vol. 62, no. 12, pt. 2, pp. 1535, 1537, 1538, 1542, 1543, and 1544). Much more detailed scientific papers on most of these subjects are being prepared and will include a considerable quantity of data collected since April 1951. 


\section{CONTENTS}

Page

Distribution of uranium deposits in the United States, by E. P. Kaiser and

L. R. Page......................

Pitchblende deposits in the United States, by Robert U. King, Frank B. Moore,

and E. N. Hinrichs ................. 8

Uranium in fluorite deposits, by

V. R. Wilmarth, H. L. Bauer, Jr.,

M. H. Staatz, and Donald G.

Wyant...................... 1
Secondary uranium deposits in the United States, by Frederick Stugard, Jr. , Donald G. Wyant, and Arthur J. Gude 3d.... 19

Some uranium deposits in sandstones, by Donald G. Wyant, Ernest P. Beroni, and Harry C. Granger ............... 26 Uranium in black shales, lignites, and limestones in the United States, by Garland B. Gott, Donald G. Wyant, and Ernest P. Beroni 31

\section{ILLUSTRATIONS}

Figure 1. Distribution of uraniferous deposits in the United States (exclusive of pegmatites and black shales). 2

2. Relation of structurally controlled uranium deposits to pre-Cambriar rocks...............4

3. Relation of structurally controlled uranium deposits to post-Triassic intrusives............5

4. Relation of structurally controlled uranium deposits to Tertiary volcanic rocks.............6

5. Distribution of uraniferous deposits with stratigraphic control ....................

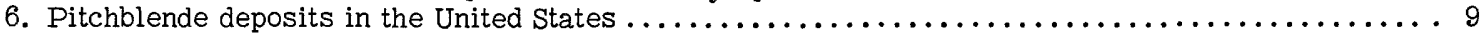

7. Relation of pitchblende deposits to bostonite dikes in the Front Range mineral belt, Colorado......11

8. Sections showing depth of pitchblende deposits, Colorado . . . . . . . . . . . . . . . . . .

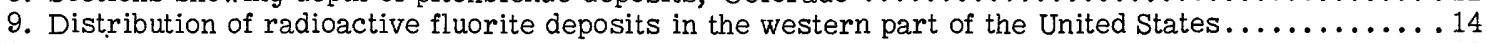

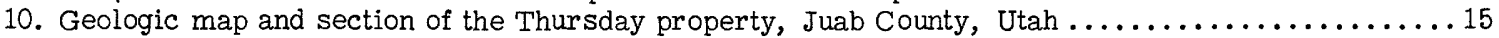

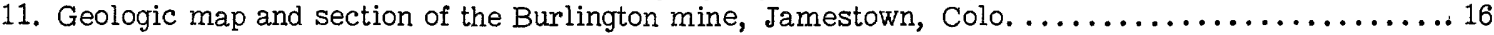

12. Geologic maps of the Fluorine Queen property, Juab County, Utah...................

13. Chart showing chemical grouping of common secondary uranium minerals.................

14. Diagram showing apparent zonal relationships of secondary and primary uranium minerals

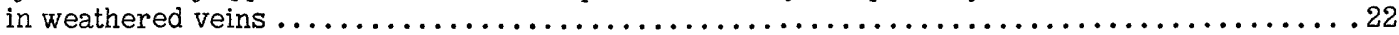

15. Section along west face of upper cut, East Slope no. 2 uranium prospect, Piute County, Utah.....23

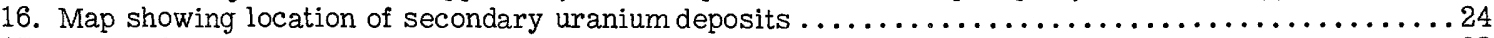

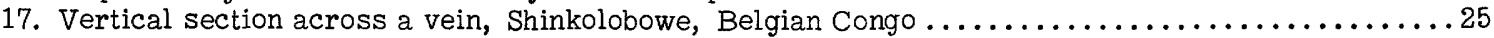

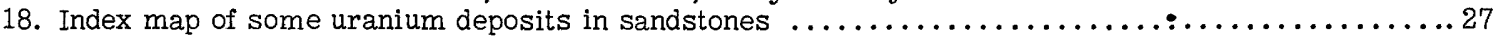

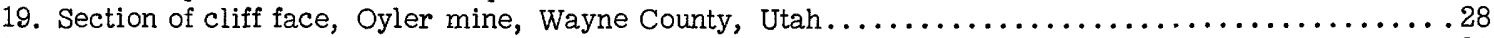

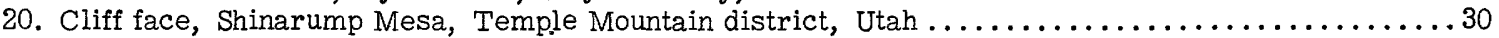

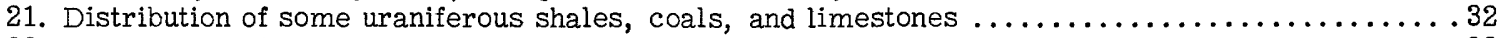

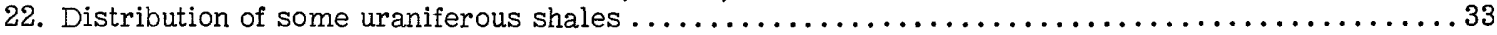

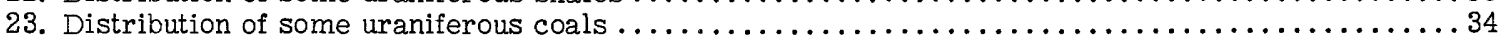




\title{
SELECTED PAPERS ON URANIUM DEPOSITS IN THE UNITED STATES
}

\author{
DISTRIBUTION OF URANIUM DEPOSITS IN THE UNITED STATES
}

By E. P. Kaiser and L. R. Page

\section{ABSTRACT}

Uranium deposits in the United States may be grouped as: (1) deposits with structural control, and (2) deposits with stratigraphic control. The deposits with structural control include veins, breccias, and pipes; disseminated deposits associated with fractures; pyrometasomatic deposits; and pegmatites. The deposits with stratigraphic control include (1) phosphates, carbonaceous shales, and lignites; (2) limestone and dolomite; (3) deposits of the carnotite type; and (4) surficial or caliche deposits.

Most of the known uranium deposits are in the western United States. Arizona, Utah, and Colorado contain the largest number of deposits.

The deposits with structural control, except the uraniferous pegmatites, are commonly in or related to igneous rocks of post-Cretaceous age, and many of them are associated with Tertiary volcanic rocks. Notably few deposits are genetically related to pre-Cambrian rocks and to Jurassic intrusives. The pegmatite deposits of the western United States are believed to be pre-Cambrian; those of the eastern United States are post-Devonian.

Carbonaceous shales, phosphates, and lignites are restricted, for the most part, to terranes of Paleozoic and Tertiary age. Most of the carnotite-type deposits are in sedimentary rocks of Mesozoic age, and the most productive deposits are in rocks of Jurassic age.

Study of the distribution of known deposits indicated that the principal favorable areas for further prospecting are those in or near Triassic and Jurassic sedimentary rocks and Tertiary igneous rocks.

The U. S. Geological Survey started an intensive study of uranium deposits in 1944. This program was carried out at first on behalf of the Manhattan Engineer District and later on behalf of the Atomic Energy Commission.

This paper and the five following papers will attempt to compile the fragmentary information on uranium deposits that has been accumulated during the past few years by the Geological Survey. Much unpublished information on uranium has been collected over a period of years by many members of the Survey, and this information has served as the basis for many of the more recent, more intensive studies. Particular acknowledgment should be made of the early work by C. E. Prouty, J. O. Harder, S. E. Clabaugh, A. L. Slaughter, J. M. Nelson, C. W. Chesterman, and F. H. Main, formerly with the Survey, and of A. P. Butler, $'$ F. W. Stead, and D. G. Wyant, still with the Survey.

The uranium deposits of the United States are of two broad types--those with structural control and those with stratigraphic control. These two types are, of course, not mutually exclusive. The deposits with structural control can be further subdivided into the following groups: (1) veins, breccias, and pipes; (2) disseminated deposits; (3) pyrometasomatic deposits; and (4) pegmatites. Deposits with stratigraphic control include: (1) phosphates, (2) black shales, (3) limestones and dolomites, (4) lignites, (5) deposits in sandstones, and (6) surficial or caliche deposits.
The distribution of localities where uraniferous deposits, except pegmatites and black shales, have been studied is shown in figure 1. Deposits of vein type, other structurally controlled deposits, and deposits with stratigraphic control have been indicated. The structurally controlled deposits are most abundant in Arizona, Utah, and Colorado.

Of the structurally controlled deposits, the vein-type deposits are most numerous and have been found in most of the western States. They include fissure veins, shear zones and stringer zones, and silicified zones or reefs. Most of the domestic production of pitchblende has come from deposits of the vein type, but in 1951 pitchblende was produced from several deposits with stratigraphic control. At Marysvale, Utah, the recently discovered deposits of the secondary minerals--uranophane, autunite, and torbernite--occur in the upper part of pitchblendebearing vein structures.

True disseminated deposits of uranium minerals are not common; an example is the Red Bluff prospect in Arizona (Kaiser, 1951), where uranium is disseminated in pre-Cambrian quartzite. At many places secondary minerals occur on fracture surfaces in both igneous and sedimentary rocks, with no obvious major structural or stratigraphic control. These are generally of little interest, except as possible indicators of larger deposits.

Pyrometasomatic uranium deposits occur in the Goodsprings district, Nevada (Harder and Wyant, 


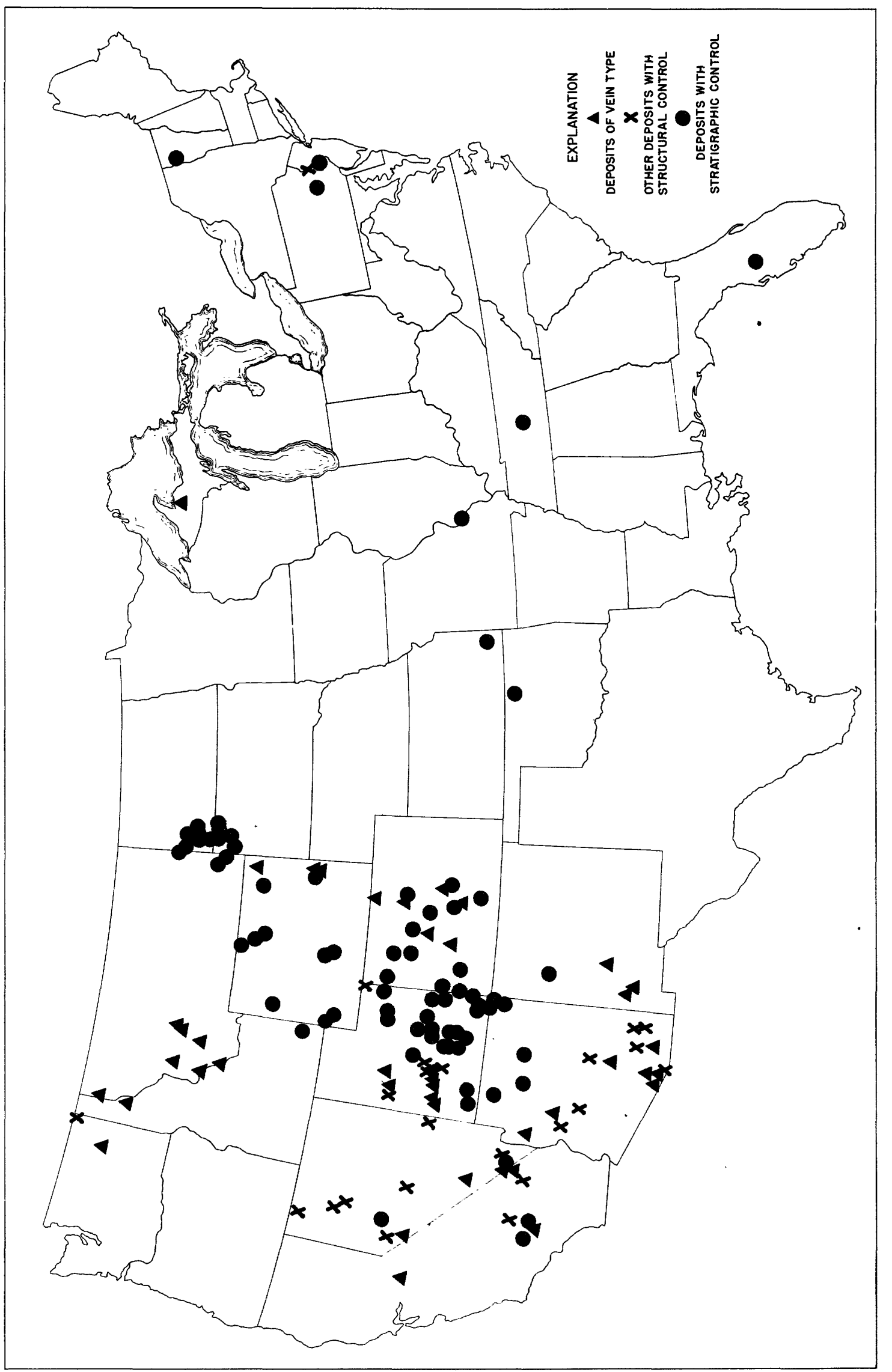

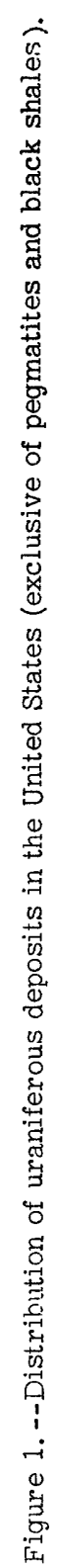


1944 , p. 36), where secondary uranium minerals are associated with oxidized lead, zinc, and copper minerals. At the Stalin's Present prospect, Pershing County, Nev, , a narrow band of lime-silicate rock in granite contains uraninite.

Pegratites that contain uranium minerals have been found in all pegmatite districts in the United States, but they rarely are more than mineralogical occurrences (Page, 1950).

The stratigraphically controlled deposits are widespread. The carnotite deposits in the Morrison formation of the Colorado Plateaus have been our principal domestic source of uranium (Fischer, 1942; 1950). The uraniferous phosphates (McKelvey, 1949; McKelvey and Nelson, 1950), black shales, and lignites are of wide extent and in the aggregate contain a large amount of uranium, but the deposits are of very low grade. Less common are the uraniferous limestones, dolomites, and caliche-type deposits.

The distribution of structurally controlled uranium deposits in relation to geologic age are shown in figures 2, 3, and 4; and the distribution of stratigraphically controlled uranium deposits is shown in figure 5 .

Figure 2 shows the structurally controlled deposits in the southwestern quarter of the United States and the outcrops of pre-Cambrian rocks. It can be seen that there is no over-all correlation between the distribution of uranium deposits and pre-Cambrian rocks in this area. This may explain why we have no deposits such as those at Great Bear Lake in Canada, which, according to Bain (1950), are related to preCambrian shield areas.

The relation of the uranium deposits in the same area to post-Triassic intrusives is indicated in figure 3. No close correlation between the intrusives and deposits is apparent; furthermore, there is a relative scarcity of deposits in and near the Sierra Nevada batholith. Details not shown in this figure that may be of significance are (1) the presence of Tertiary intrusives in the Colorado Plateaus; (2) the occurrence of the Marysvale deposits of central Utah in and near a small Tertiary stock; (3) the intimate relation of the Colorado Front Range deposits to small Laramide intrusives; and (4) the relationship between uranium veins and the rocks of the Boulder batholith of Montana.

The relation of uranium deposits to Tertiary volcanic rocks is indicated in figure 4 . The outline of the Colorado Plateaus of Fenneman (1931), has been added. Of particular interest is the grouping of uranium deposits in and near areas of Tertiary volcanic rocks in Utah, Arizona, southern California, Nevada, and Colorado, and the relative scarcity of volcanic extrusive rocks in the Colorado Plateaus, where many of the stratigraphically controlled uranium deposits occur.

Figure 5 shows the distribution of terranes, as shown on the United States geologic map, that contain stratigraphically controlled deposits. Deposits in black shales have been omitted.

The uraniferous phosphate deposits of the Permian Phosphoria formation in southeast Idaho are believed to be syngenetic and contain other metals as well as the small amounts of uranium. Phosphate deposits in the Bone Valley formation of Pliocene age in Florida are similar to those in the Phosphoria; however, only a small part of the formation is uraniferous, as is indicated by the dashed line in figure 5 .

Uraniferous black shales are widely distributed in age. Samples of the pre-Cambrian Nonesuch shale in the Michigan peninsula contain as much as 0.004 percent uranium. Black shales of late Devonian and Mississippian age that commonly are uraniferous include the Chattanooga shale of Tennessee and Kentucky, the New Albany shale of Indiana, the Antrim shale of Michigan, and the Woodford chert in the midcontinent region. Black shales of the Phosphoria formation of . Permian age are uraniferous. In contrast, the black shales of the Permian basin of Texas and New Mexico are not notably uraniferous. No known uraniferous shales of Cambrian age occur in the United States, although in Sweden, shales of that age are reported to be a current source of uranium.

The most extensive uraniferous lignites are those of early Tertiary age in North Dakota, South Dakota, Wyoming, and Montana. Uraniferous lignite of Tertiary age is also found in Nevada. Uraniferous subbituminous coals of Cretaceous age occur in western Wyoming, and some uraniferous bituminous coals of Paleozoic age occur in the midcontinent region.

The most productive uranium deposits in sandstone are in the Jurassic Morrison formation of the Colorado Plateaus, but deposits have also been found in sandstones ranging in age from Paleozoic to Tertiary.

Uranium is present in the carboniferous Milton dolomite of Vermont, in Tertiary limestone in Utah, in the Mississippian Spergen limestone in Missouri, and in the Jurassic Todilto limestone at Grants, N. Mex.

In the Red Desert area of Wyoming, schroeckingerite (Larsen and Gonyer, 1937) occurs in sands and clays of early Tertiary age, in a thin zone above the water table, and is probably a caliche-type deposit.

The following papers will describe in more detail several aspects.of domestic uranium deposits.

\section{LITERATURE CITED}

Bain, G. W., 1950, Geology of the fissionable materials: Econ. Geology, vol. 45, pp. 273-323.

Fenneman, N. M. , 1931, Physiography of western United States, New York, McGraw-Hill BookCo., Inc.

Fischer, R. P., 1942, Vanadium deposits of Colorado and Utah, a preliminary report: U. S. Geol. Survey Bull. 936-P, pp. 363-394.

1950, Uranium-bearing sandstone deposits of the Colorado Plateau: Econ. Geology,vol. 45, pp. 1-11.

Harder, J. O., and Wyant, D. G., 1944, Preliminary report on a trace elements reconnaissance in western States: U. S. Geol. Survey Trace Elements Inv. Rept. 4, 47 pp. [ Unpublished.]

Kaiser, E. P., 1951, Uraniferous quartzite, Red Bluff prospect, Gila County, Ariz.: U. S. Geol. Survey Circ. 137.

Larsen, E. S., Jr., and Gonyer, F.A., 1937, Dakeite, a new uranium mineral from Wyoming: Am. Mineralogist, vol. 22, no. 5, pp. 561-563.

McKelvey, V. E., 1949, Geologic studies of the western phosphate fields: Am. Inst. Min. Met. Fing. Trans., vol. 184, pp. 270-279.

McKelvey, V. E., and Nelson, J. M., 1950, Characteristics of marine uranium-bearing sedimentary rocks: 'Econ. Geology, vol. 45, pp. 35-53.

Page, L. R., 1950, Uranium in pegmatites: Econ. Geology, vol. 45, pp. 12-34. 


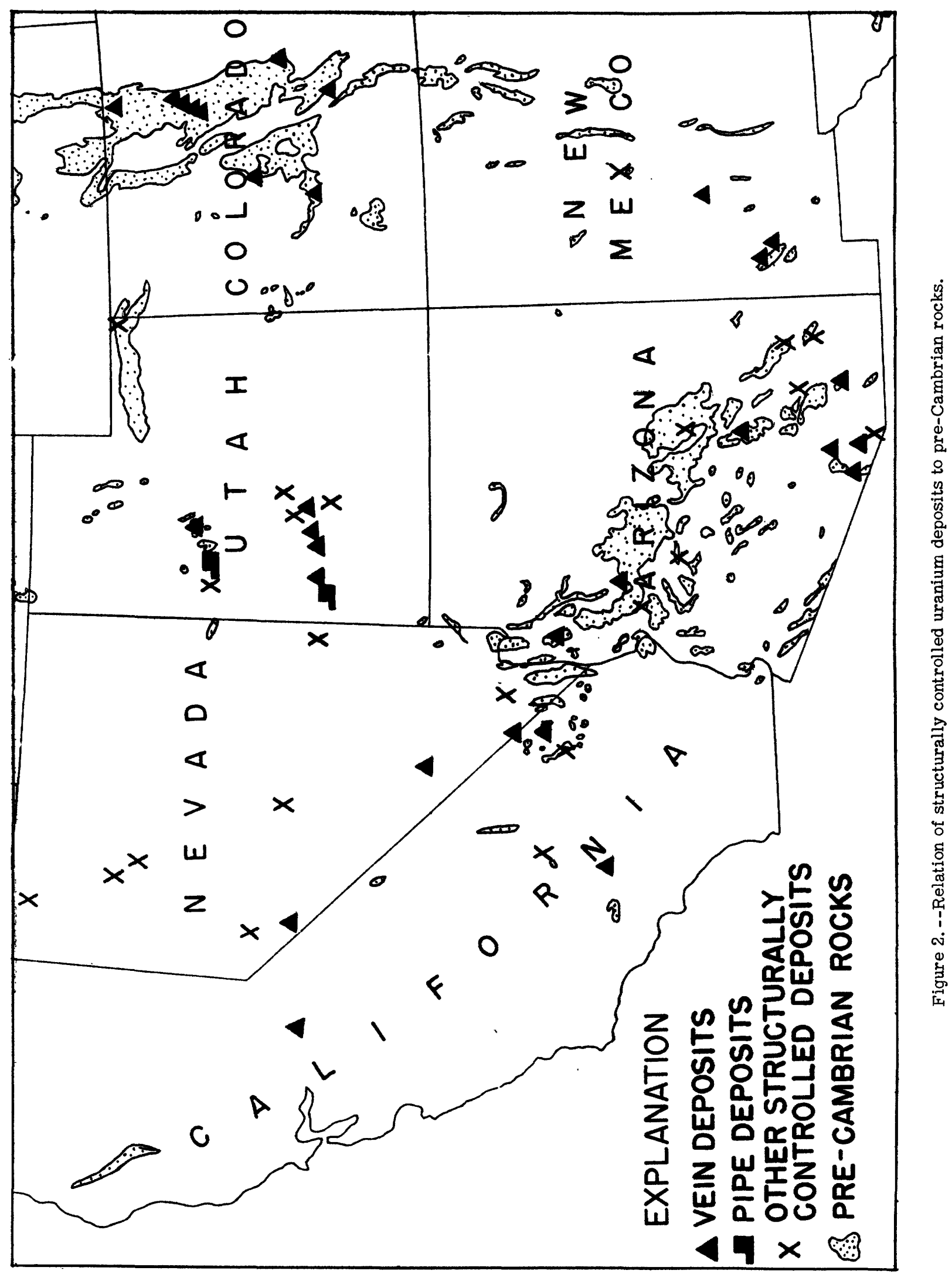




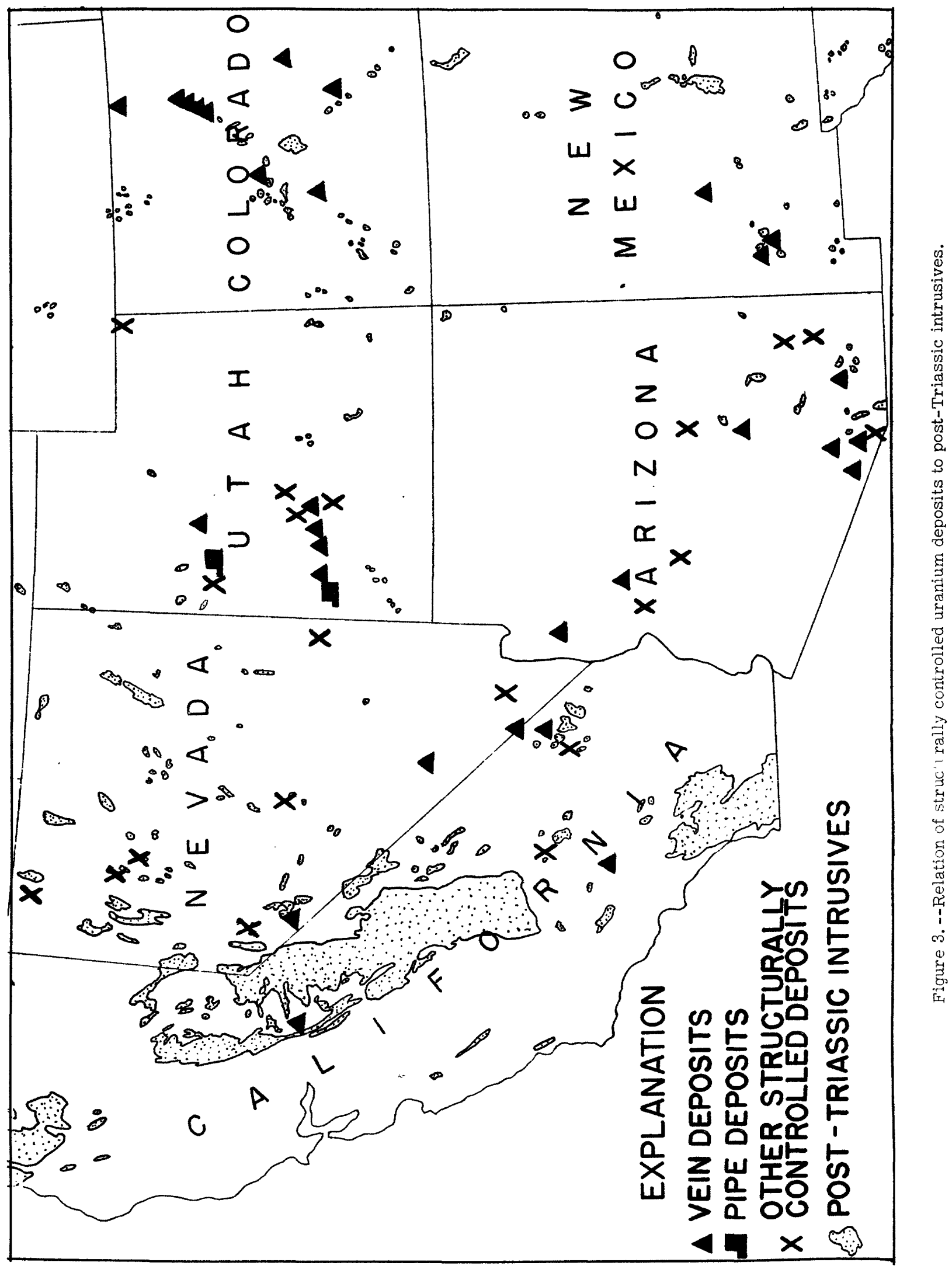




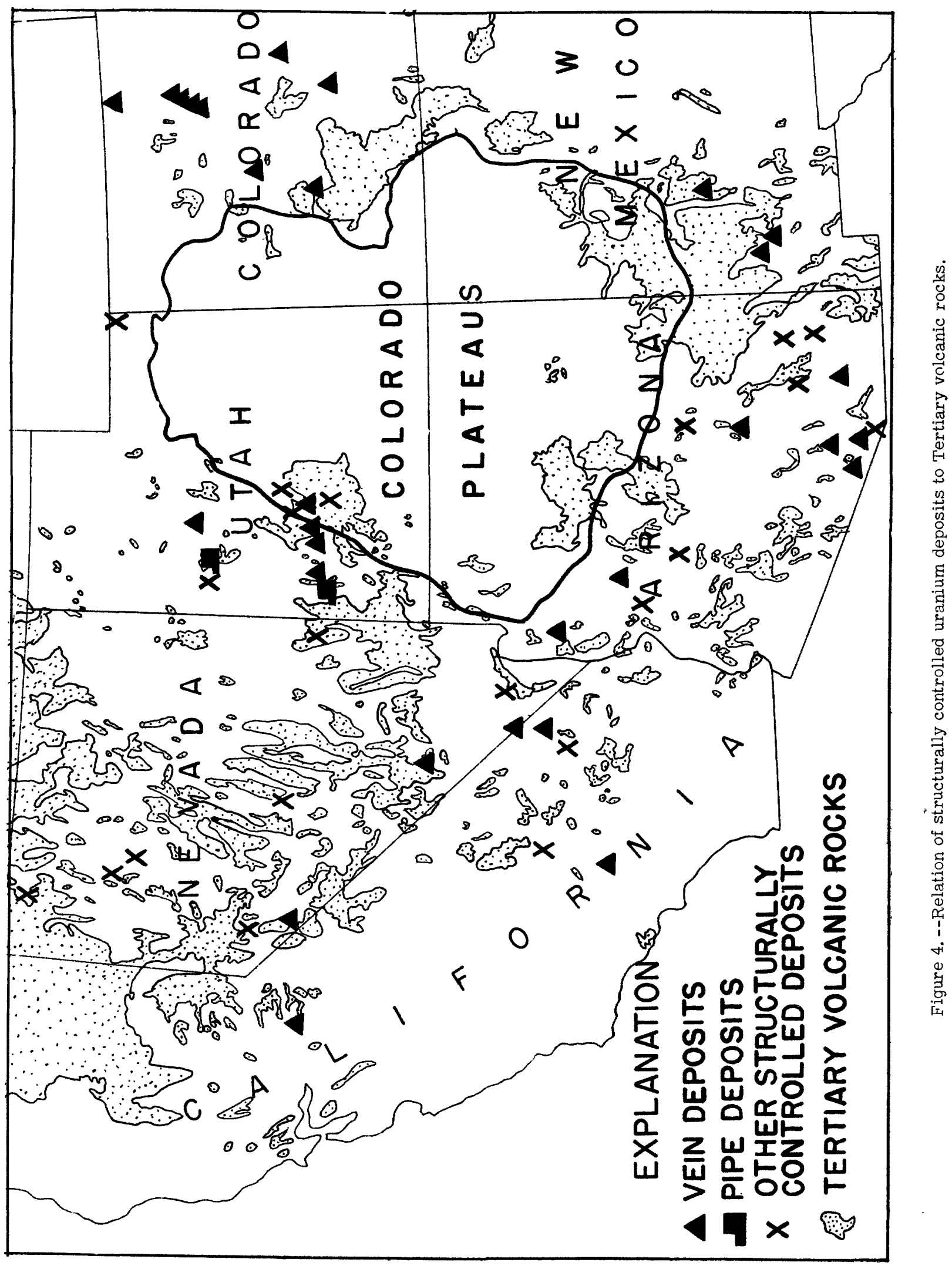




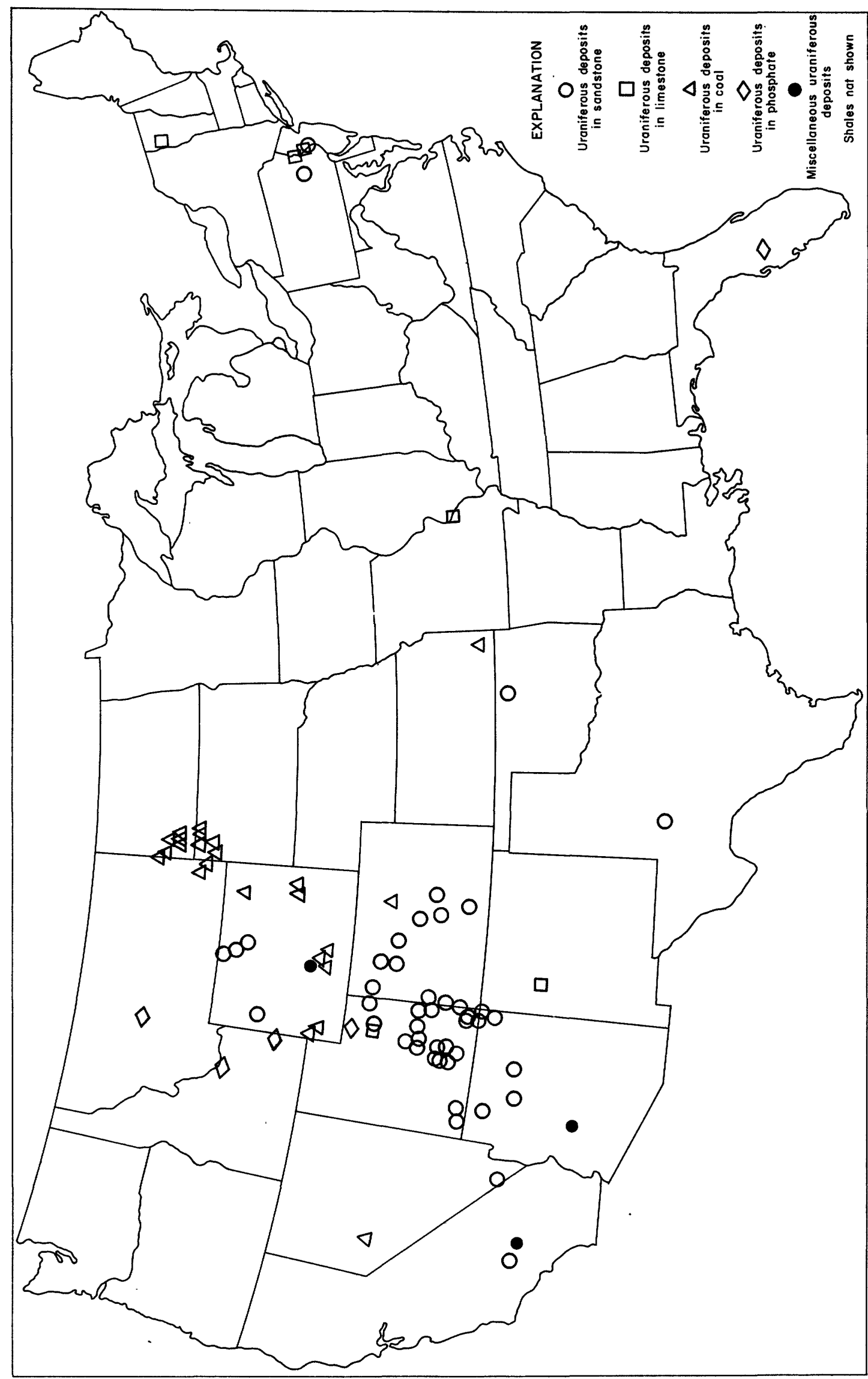

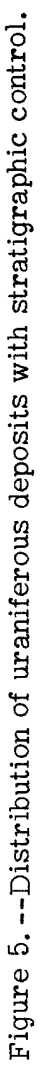




\section{PITCHBLENDE DEPOSITS IN THE UNITED STATES}

By Robert U. King, Frank B. Moore and E. N. Hinrichs

\section{AESTRACT}

Pitchblende is found in the United States in (1) veins and breccia zones, (2) pyrometasomatic deposits, (3) pegmatites, and (4) sedimentary rocks. On the basis of past production, the depnsits in veins and breccia zones are of the greatest commercial significance.

Most of the vein deposits containing pitchblende are in the Front Range mineral belt of Colorado, but a few are in Arizona, Idaho, Montana, Nevada, and Utah. The pitchblende deposits in the Front Range mineral belt appear to be coextensive with alkali-rich Tertiary intrusive rocks, but a similar relation is not known elsewhere in the United States.

Pitchblende-bearing vein deposits can be classified on the sasis $f$ mineral association as (1) quartz-sulfide type, (2) quartz-sulfide-carbonate type, (3) quartz-sulfide-carbonate-hematite type and (4) fluorite-quartz type.

Pitchblende is finely disseminated in deposits of the fluorite-quartz type. In mesothermal veins, pitchblende occurs as pods and stringers distributed erratically over relatively narrow vertical limits. In many deposits, pitchblende occurs both as hard botryoidal masses and as powdery films and coatings.

The metallic minerals commonly associated with pitchblende in vein deposits include galena, sphalerite, chalcopyrite, pyrite, silver minerals, and gold. In contrast to well-known deposits in Canada and Africa, cobalt or nickel minerals have been found in only a few of the domestic pitchblende-bearing veins. In a few places, veins containing secondary uranium minerals near the surface contain pitchblende at depth.

The relat:-nship of pitchblende-bearing veins to types of wall-rock alteration has not been clearly established.

Pitchblende occurs in many places in the United States; however, most of the domestic production has come from vein deposits in the Front Range min ral belt of Colorado.

Pitchblende was discovered in the United States at the Wood mine in the Certral City district, Colorado, in 1871. Since then it has been found in many mines in this distr ct. More recently, pitchblende deposits have been discovered in most of the other western States.

Pitchblende is found in vein and breccia deposits, in deposits in sedimentary rocks, in pegmatites, and in other deposits not readily classified in these groups. In vein deposits pitchblende occurs as hard, botryoidal masses, as so ty $1 \mathrm{lms}$ and coatings, and as microscopic granular disseminations. In sedirrentary rocks it occurs as disseminations in sandstone and limestone. In pegmatites, uraninite, rathe. han pitchblend, is the most common uranium mineral but is of little economic importance

Vein and breccia deposits of pitchblende are found in igneous rocks in Lincoln County, Wash., near Clancey, Jefferson County, Mont. ; at Marysvale, Piute County, Utah; in Pima County, Arız.; and in more than 20 deposits in the Front Range mineral belt of Colorado (fig. 6). Vein deposits in sedimentary or metamorphic rocks occur in the Coeur diAlene district, Idaho, in Niobrara County, Wyo.; in Baraga
County, Mich.; and in San Miguel County, Colo. Pitchblende is disseminated in sedimentary rocks at Hack's Canyon, Ariz.; White Canyon, Utah; and at Grants, N. Mex. In Pershing County, Nev., pitchblende occurs with contact-metamorphic minerals in a thin dark band in granite.

Vein deposits of pitchblende can be classified on the basis of mineral association as (1) quartz-sulfide type, (2) quartz-sulfide-carbonate type, (3) quartzsulfide-carbonate-hematite type, and (4) fluoritequartz-sulfide type

Massive and sooty pitchblende occurs in veins of the quartz-sulfide type, such as the deposits at Quartz Hill in the Central City district, Colorado: at Prai.ie Divide, Larimer County, Colo.; at Ralston Creek, Jefferson County, Colo.: in Lincoln County, Wash. : and near Clancey, Mont. Masses or pods of pitchblende, sparsely and erratically distributed in veins, are as much as 8 inches thick by more than 10 feet in diameter although such occurrences are unusual. These pods contain from 70 to 80 percent $\mathrm{U}_{3} \mathrm{O}_{8}$. Pyrite, galena, and sphaler te commonly are associated with pit hblende in these deposits, and chalcopvrite is present 'n some but generally is not abundant. Fin $g$ ained dense quartz is the most common gangue mineral. In Lincoln County, V.ash. , molybdenite is $\mathrm{pr} \in$ sent in addition to the other base metal sulfides. The Colorado quartz-sulfide deposits contain gold and minor silver, and were valuable chiefly 


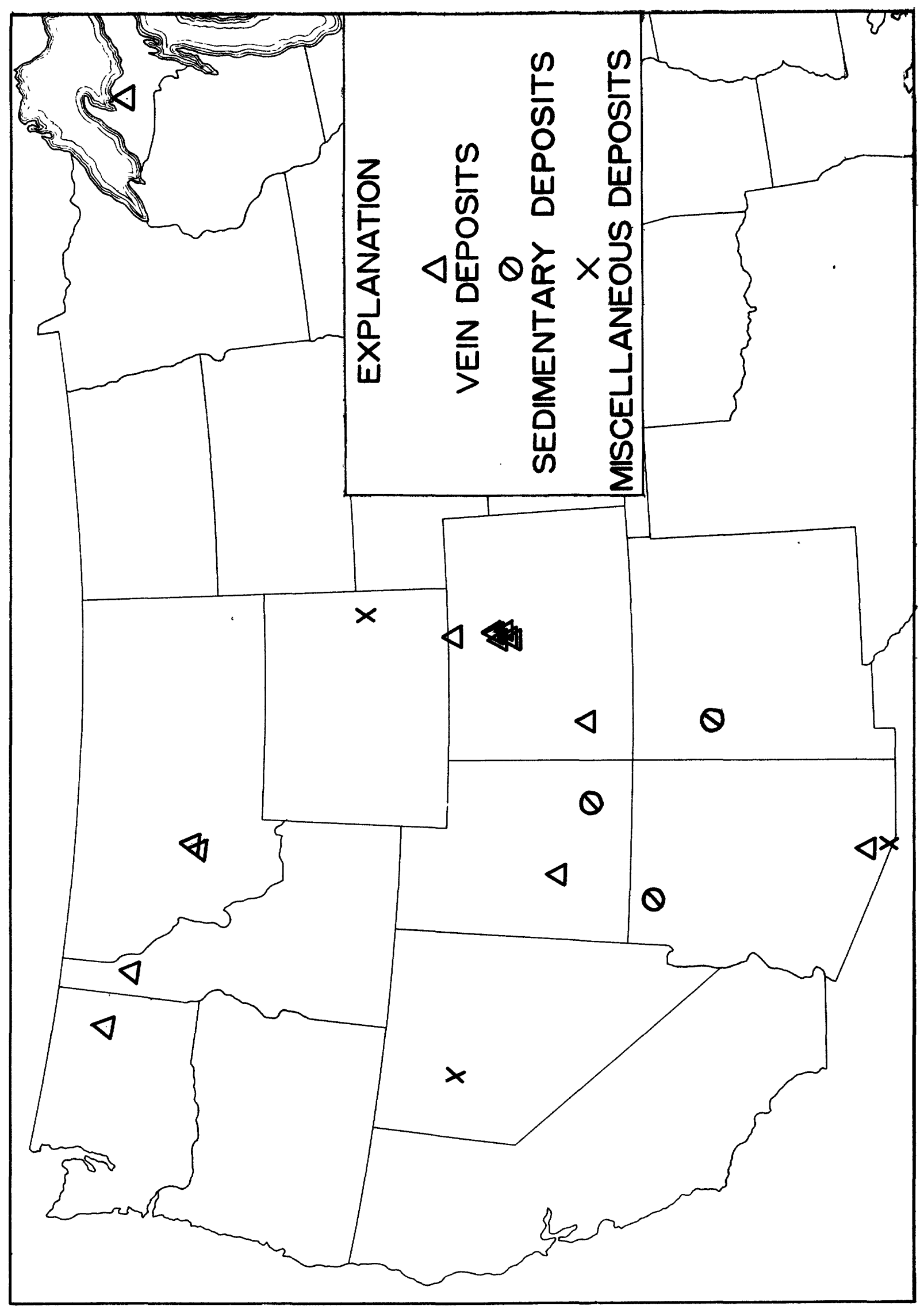

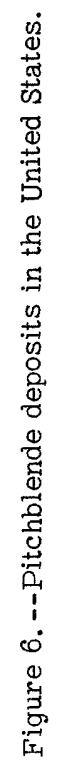


for the gold. The miners in the Central City district have learned by experience that an inverse relationship exists between the gold and the pitchblende content--where pitchblende was found the gold content was low.

Pitchblende vein deposits of the quartz-sulfidecarbonate type are typified by those in the Lawson district and in the Caribou mine, Colorado. These pitchblende ore bodies are generally smaller than those in the quartz-sulfide veins of the Front Range; however, isolated pods may contain as much as 70 percent uranium. Silver is the most common precious metal, and the sulfide minerals include pyrite, galena, sphalerite, and minor amounts of chalcopyrite and tetrahedrite. Quartz, dolomite, and calcite are the common gangue minerals, and at the Caribou mine carbonates locally comprise the entire vein filling.

Pitchblende in veins of the quartz-sulfidecarbonate-hematite type occurs as microscopic grains or aggregates disseminated in dense quartz-hematite or jasperoid and as fine-grained streaks at the edges of carbonate veinlets; for example, the deposits in the Coeur d'Alene district, Idaho. Typical veins of this type contain silver minerals, galena, sphalerite, gersdorffite, chalcopyrite, and a siderite-quartz gangue. Reddish hematite-stained quartz veinlets also are present at Caribou.

The fluorite-sulfide-quartz type of pitchblende veins are represented by deposits in the Jamestown district, Colorado, and the Marysvale district, Utah. At Jamestown uraninite occurs as microscopic grains disseminated in fluorite veins and also in a quartzmonzonite breccia that has a fluorite matrix. Pyrite, galena, sphalerite, and rarely chalcopyrite are sparsely disseminated through the deposits. At Marysvale pitchblende occurs as small hard nodules and as sooty streaks and masses with pyrite and fluorite.

The pitchblende-bearing veins in the United States cut rocks ranging in age from pre-Cambrian to Tertiary, but most of the known deposits are in pre-Cambrian granitic and metamorphic rocks. The pitchblende deposits at the Caribou mine, Colorado; Clancey, Mont. ; Pershing County, Nev. ; and Marysvale, Utah, are in or near granite, monzonite, or quartz monzonite intrusives of late Cretaceous or Tertiary age.

With few exceptions, the pitchblende-bearing veins in Colorado are confined to the northeastern half of the Front Range mineral belt, an area characterized by the occurrence of numerous bostonite dikes (fig. 7). The dikes are two to five times as radioactive as the enclosing pre-Cambrian granitegneiss and schist, in places containing as much as 0.01 percent uranium. Sume of the pitchblendebearing veins cut the dikes.

Sericite and clay minerals seem to be the more common alteration products associated with pitchblendebearing veins in the Front Range of Colorado. The wall rock of the pitchblende veins at the Caribou mine has been intensely altered. Pyroxene has been converted to chlorite, feldspars to clay minerals, and feldspars and biotite to sericite. Calcite and siderite cut and replace feldspars, and quartz replaces earlier minerals.
In the Colorado pitchblende deposits, secondary minerals have been noted in a few places. In the Lawson district torbernite and autunite occur near the surface and pitchblende occurs at depth in nearby veins, but primary and secondary minerals have not yet been found in the same veins. Johannite and zippeite are the only secondary minerals that have been found in the Central City district.

Torbernite has been identified at Jamestown in a pitchblende-bearing fluorite deposit. Oxidized pyrometasomatic lead-zinc-copper deposits at Goodsprings, Nev., contain the secondary uranium silicate, kasolite, and the phosphate, dumontite, which may have developed from the weathering of pitchblende.

Pitchblende is associated with copper sulfides and secondary uranium minerals in sandstone in the basal part of the Shinarump conglomerate at White Canyon, Utah. Pitchblende has also been identified from deposits in the Coconino sandstone at Hack's Canyon, Ariz., and in the Todilto limestone at Grants, N. Mex. At Grants, uranophane, carnotite-tyuyamunite, fluorite, and calcite are also present.

In the United States the metals commonly associated with pitchblende are lead, zinc, copper, silver, and gold. Analyses of samples from the 1040-foot level in the Caribou vein, Colorado, indicate that pitchblende is most abundant in the parts of the vein richest in copper, lead, and silver, and is less abundant in those parts rich in zinc. This relationship has not been established in other deposits in the United States.

In contrast to foreign deposits, cobalt, nickel, and bismuth generally are not closely associated with pitchblende deposits in the United States. In the Coeur d'Alene district, Idaho, cobalt occurs near but not within the pitchblende-bearing veins. Small quantities of cobalt are present in the deposits of White Canyon, Utah, and at Caribou, Colo.

Pitchblende veins have been considered by some writers as shallow deposits, but recent work indicates that they may have a greater vertical range than has hitherto been suspected. Figure 8 shows that the range of these veins in the Front Range, Colo., is at least 1,000 feet. At Kirk mine in the Central City district of Colorado, pitchblende is known from the surface to a maximum depth of 400 feet where the ore shoot may bottom. In the Caribou mine and in the mines of the Lawson district, Colorado, pitchblende occurs at depths of about 1,000 feet below the surface; at the Sunshine mine, Idaho, it occurs on the 3,100- and 3,700-foot levels. The vertical range in which the pitchblende occurs in each place, however, appears to be rather short--about 200 to 400 feet.

In summary, by far the greatest number of the pitchblende deposits found in the United States to date have been in the Front Range mineral belt of Colorado. Pitchblende is most common in deposits containing copper, lead, and silver; although, in foreign deposits, cobalt, nickel, and bismuth are considered favorable associations. Recently discovered deposits indicate that pitchblende may be found in veins that have a greater vertical range than has hitherto been suspected. 


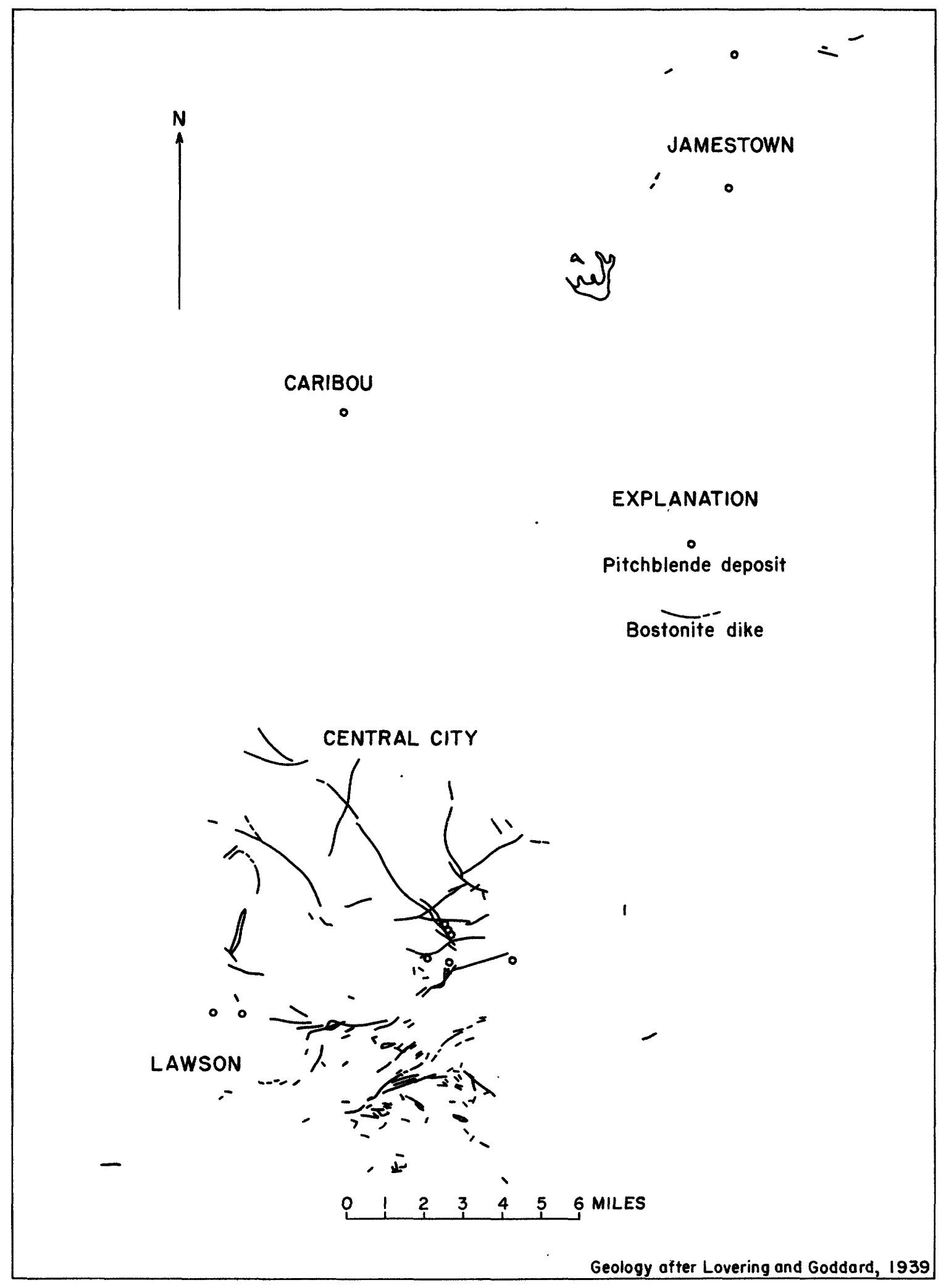

Figure 7. --Relation of pitchblende deposits to bostonite dikes in the Front Range mineral belt, Colorado. 


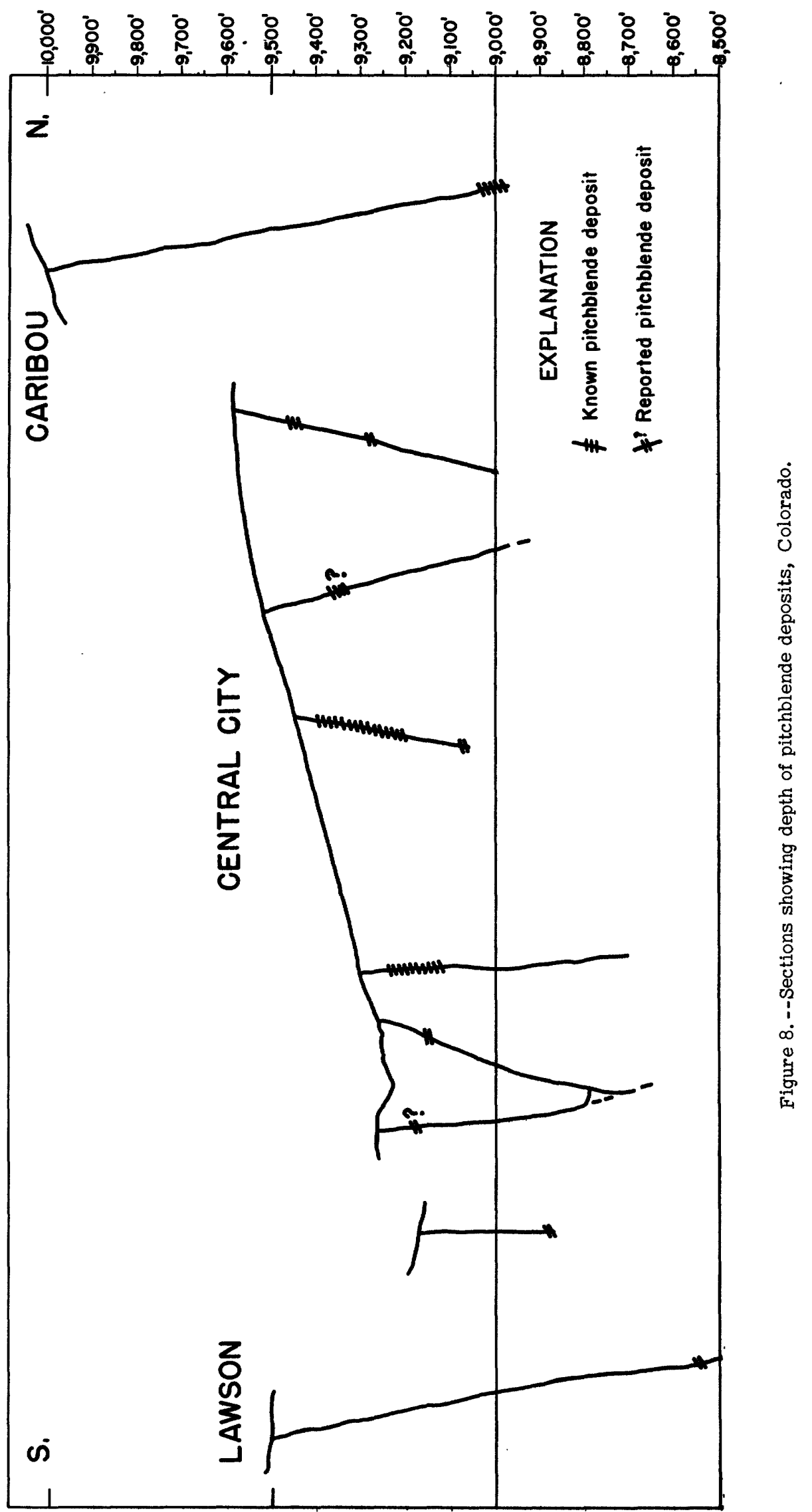




\section{URANIUM IN FLUORITE DEPOSITS}

By V. R. Wilmarth, H. L. Bauer, Jr., M. H. Staatz, and Donald G. Wyant

\section{ABSTRACT}

The association of small quantities of fluorite with uranium minerals in veins has been reported for many localities. Recent studies in Colorado, Utah, Wyoming, and New Mexico further indicate that uranium is a common constituent of many fluorite deposits.

Fluorite deposits known to contain uranium occur in breccia zones, veins, pipes, and bedded replacement deposits. These deposits can be grouped on the basis of essential minerals as (1) fluorite, (2) fluorite-quartz-sulfide, and (3) fluorite-sulfide deposits. The deposits contain pitchblende or other primary uranium minerals, together with such secondary uranium minerals as schroeckingerite, torbernite, autunite, uranophane, carnotite, and sklodowskite.

In some deposits the uranium occurs as fine-grained primary minerals disseminated through the fluorite ore body; in others the uranium is in the fluorite itself in a form not yet identified. Secondary uranium minerals coat fracture surfaces and vugs in both the ore bodies and adjacent wall rocks.

Purple fluorite is commonly associated with radioactive deposits, but because of the many exceptions to this rule it is of limited value.

Uranium minerals are associated with fluorite in fluorite deposits and in polymetallic veins in the United States and other countries. The fluorite veins at Wolsendorf, Bavaria, are the only ones that have furnished appreciable quantities of uranium ore. Uranium has been found in 18 fluorite deposits (fig. 9) in the western States, and although no uranium has been produced as a byproduct of fluorite mining, recent studies by the U. S. Geological Survey on behalf of the Atomic Energy Commission have shown that some of these deposits may yield significant quantities of uranium.

The fluorite deposits known to contain radioactive minerals occur as veins, breccia zones, pipes, and tabular to irregular replacement bodies, and most, if not all, of these deposits are related to Tertiary igneous activity. The deposits, however, are in preCambrian granites, Middle Paleozoic to Tertiary sedimentary rocks, and Tertiary igneous rocks.

The uranium-bearing fluorite veins in all deposits are similar in that they have irregularly mineralized margins. Typical fluorite veins--such as those at the Thursday property (fig. 10)--are from 6 inches to 25 feet thick and from 5 to 1,000 feet long. In some veins discontinuous tabular shoots of fluorite are common; in others, pockets, seams, and small rodlike bodies are abundant. The average fluorite content in these deposits is as much as 80 percent and the uranium content ranges from 0.003 to 0.45 percent.

Uraniferous fluorite breccia zones in the Jamestown district, Colorado, and in southwestern New Mexico, are from 5 to 50 feet thick and from 40 to 350 feet long. The Burlington mine (fig. 11) is typical of mines in the district that have been worked to depths of more than 600 feet. Fluorite forms the matrix of the breccia, and the content of each deposit varies widely. The amounts of fluorite and uranium in the breccia zones studied to date are, in general, less than those in vein deposits.

Uraniferous fluorite pipes have been found only in the Thomas Range, Utah, where they are important sources of fluorspar. Some of the pipes are circular; others--such as the Fluorine Queen shown in figure 12-are elliptical or irregular in plan, and all pipes plunge at steep angles. The circular pipes are as much as 15 feet in diameter and have a smooth sharply defined contact with the enclosing dolomite. The elliptical or irregular pipes, in plan view, range in size from 10 feet by 25 feet to 25 feet by 145 feet. The contacts are ragged and indefinite in outline, and many small fluorite veinlets extend outward from the main body into the country rock. One of the fluorite pipes has been $\mathrm{m}_{i}$ ined through a vertical distance of more than 220 feet. The fluorspar that has been recovered contains from 65 to 95 percent $\mathrm{CaF}_{2}$ and from 0.005 to 0.33 percent uranium.

Near Sundance, Wrn., tabular and irregular replacement deposits occur along fractures and bedding planes in limestones. They vary in size from a few widely spaced crystals of fluorite to discontinuous masses 3 feet wide and 50 feet long. At the Poison Lake lode, Beaverhead County, Mont., a series of small fissure fillings and replacement bodies form a zone 75 feet wide and 200 feet long. Both the Sundance and the Beaverhead County deposits are highly radioactive, but most of the radioactivity is caused by thorium. 


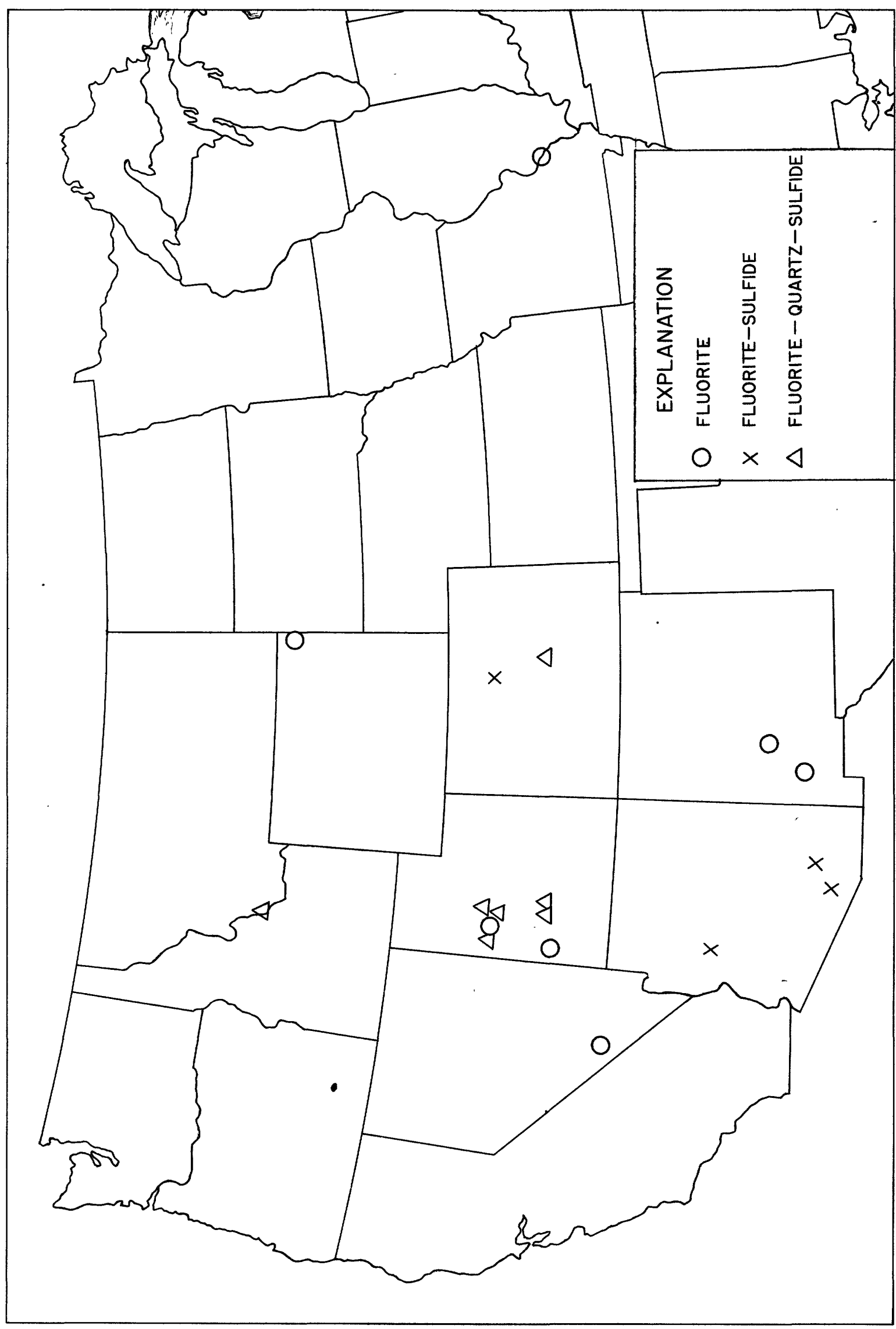




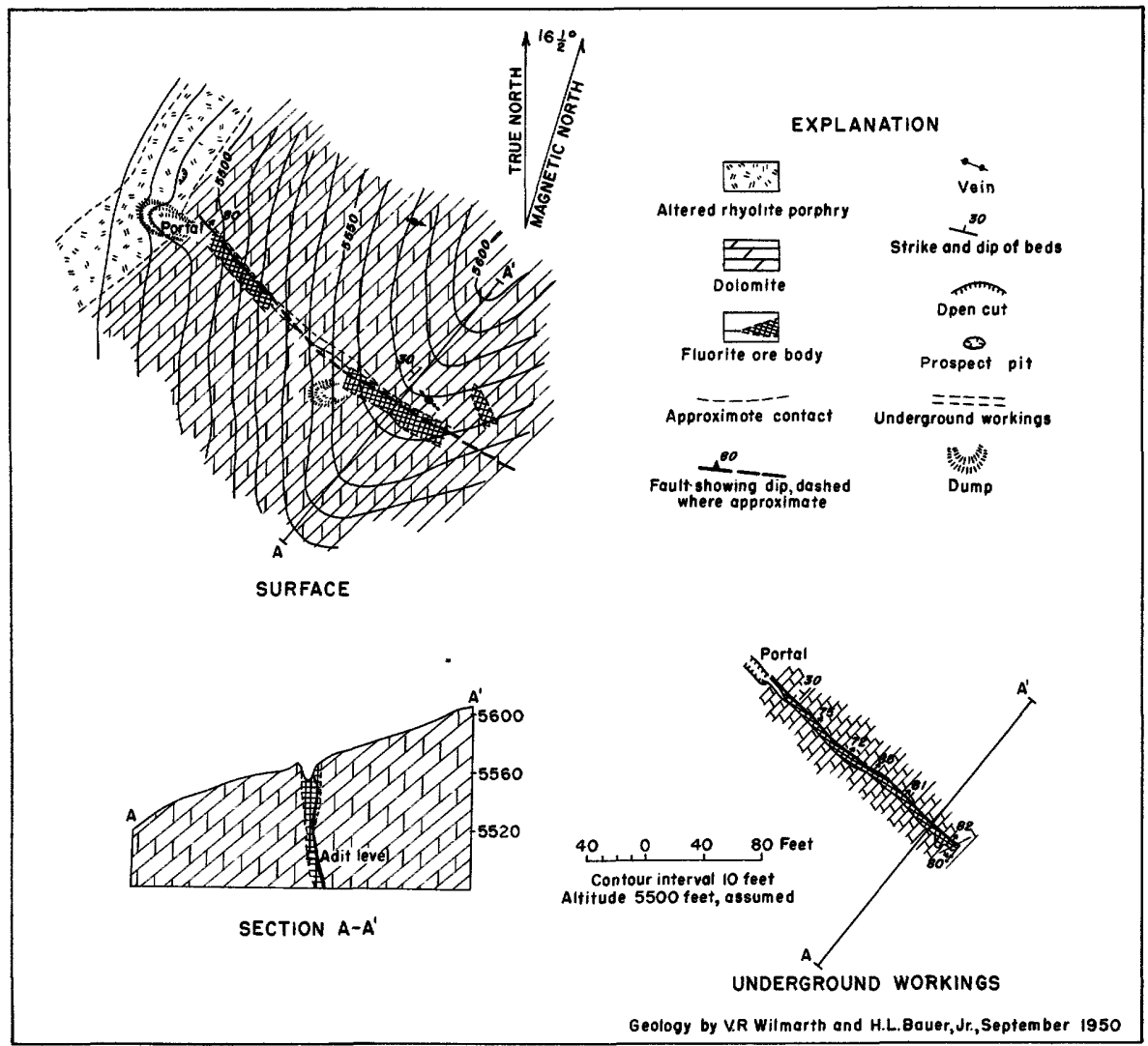

Figure 10.--Geologic map and section of the Thursday property, Juab County, Utah.

Uraniferous fluorite deposits are similar in mineralogy and can be grouped according to their essential mineral constituents as fluorite, fluoritequartz-sulfide, or fluorite-sulfide deposits.

Uraniferous deposits (fig. 9) essentially composed of fluorite contain as much as 0.33 percent uranium, but primary uranium minerals have not been identified. Either the uranium mineral is exceedingly fine-grained, or the uranium may substitute for calcium in the calcium fluorite molecule. In some of the deposits small quantities of secondary uranium minerals coat fracture surfaces in both the ore bodies and adjacent wall rocks. Carnotite has been found in the Thomas Range deposits, Utah; autunite and uranophane at the Staats mine, Beaver County, Utah; uranophane at the Terry property, Sierra County, N. Mex.; and autunite from the Hines property, Grant County, N. Mex. The fluorite in this type of deposit varies from a fine-grained pulverulent earthy variety in pipes to a coarsely crystalline variety common in breccia zones, veins, and irregular replacement deposits. Except for the white earthy highly uraniferous fluorite of the Thomas Range deposits, all radioactive fluorite so far as known is dark purple to black. Common gangue minerals are clay minerals, barite, chert, carbonates, and wad.

The fluorite-quartz-sulfide deposits typically occur as fissure veins either near the contact of acid igneous rocks or within the igneous rocks. Deposits of this type have been found in Utah, Colorado, Wyoming, and Montana. The deposits in Utah and Colorado contain secondary uranium minerals, which commonly coat fractures in the dark-purple fluorite. In the Honeycomb Hills, Utah, the uranium minerals sklodowskite, uranocircite, and soddyite coat crystal faces of pale-green fluorite. Kasolite, a lead-uranium silicate, has been identified in the Saint Peters dome area of Colorado; autunite at Indian Creek, Utah; uranophane in the eastern part of the Thomas Range, Utah; and autunite and other uranium minerals in the Marysvale district, Utah. No uranium minerals have been identified with the dark radioactive fluorite at the Poison Lake lode, Montana, and the Sheeprock Mountains, Utah. Nonradioactive, pale-green fluorite predominates in the more siliceous parts of the fluoritequartz-sulfide deposits. In all deposits the fluorite is erratically distributed as small irregular masses and narrow veinlets that are associated with massive and finely crystalline white quartz. The primary sulfide minerals--galena, sphalerite, chalcopyrite, and pyrite-commonly are in blebs, pockets, or narrow veinlets that cut quartz and fluorite. The accessory secondary minerals--azurite, malachite, limonite, opal, clay minerals, and hematite--are locally abundant.

Uraniferous deposits of fluorite and metallic sulfides without quartz occur as veins and breccia zones in pre-Cambrian to Tertiary igneous rocks in Colorado and Arizona. Pitchblende, uraninite, autunite, and torbernite are associated with finely crystalline to massive dark-violet or black fluorite. In the Jamestown district, Colorado, uraninite has been identified as discrete grains disseminated through 


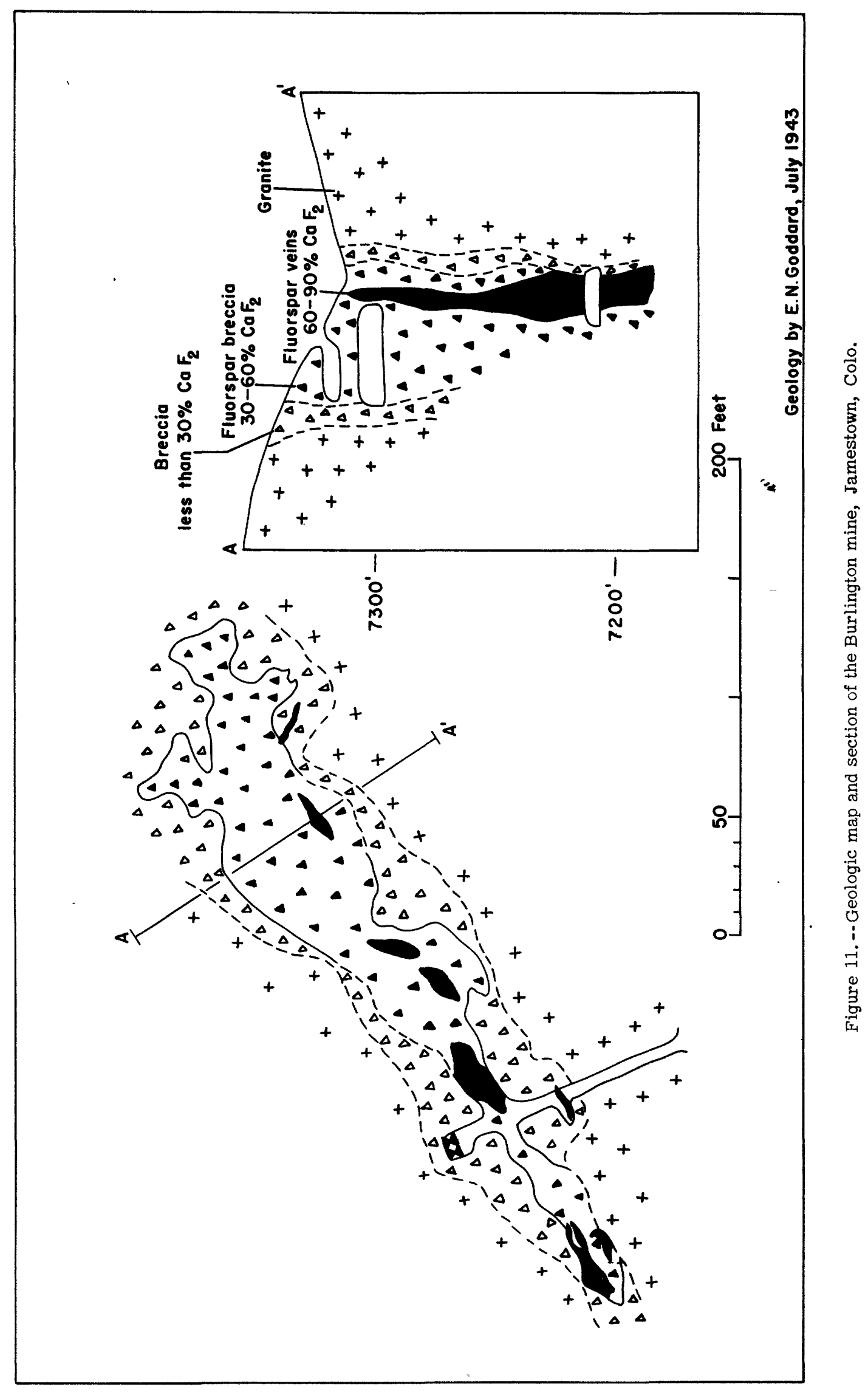




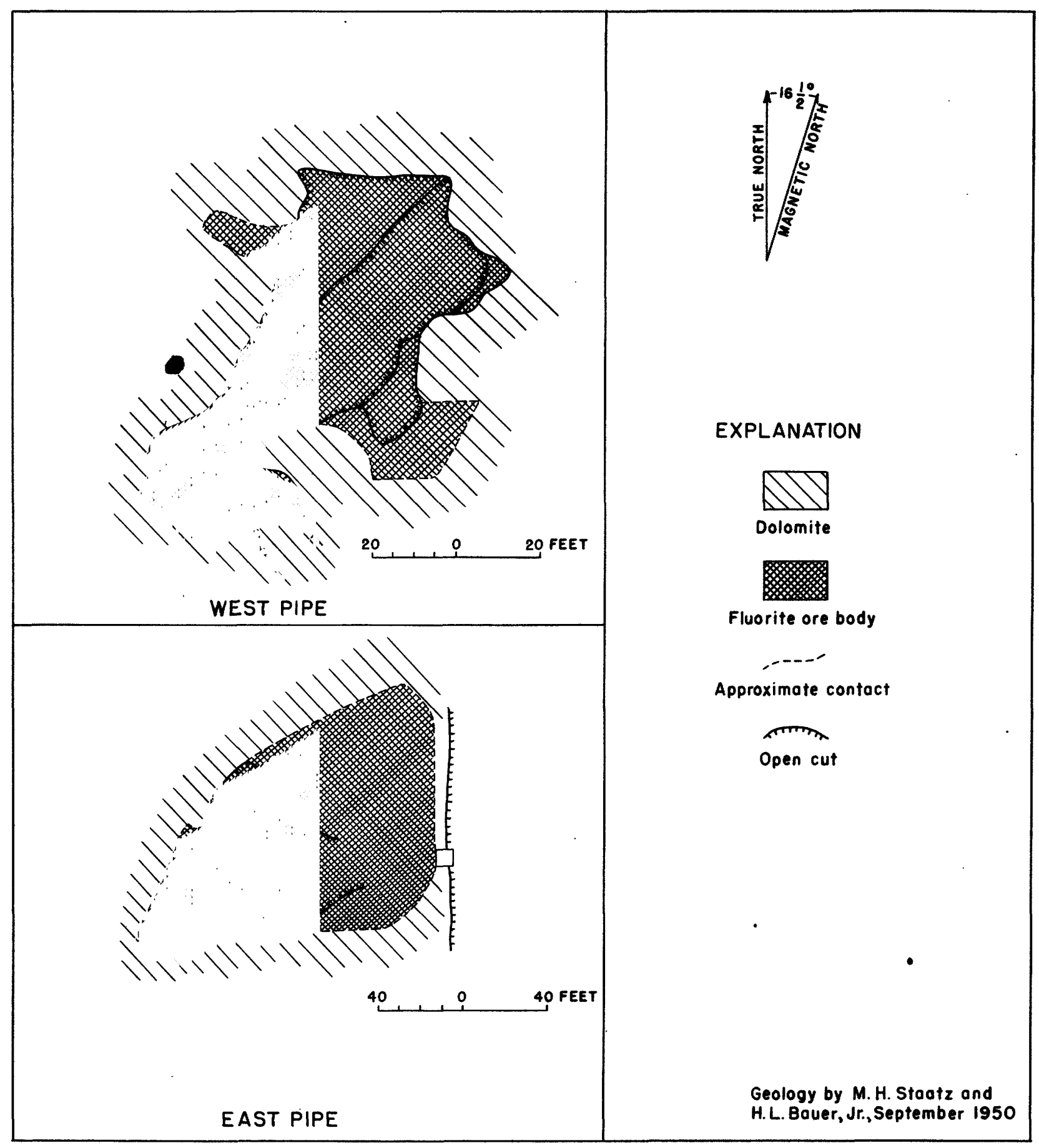

Figure 12.--Geologic maps of the Fluorine Queen property, Juab County, Utah. 
the fluorite of the deposits, and torbernite occurs on fractures in fluorite and altered granodiorite in the Nations Treasure mine in this district. Pitchblende occurs in narrow veinlets in the fluorite veins on the Black Dike claims, Pima County, Ariz. Autunite is found along fractures in schist at the Sure Fire property in the same county. No uranium minerals have been identified at the Red Hills deposit, Yuma County, Ariz., but abnormal radioactivity was noted in close association with lavender fluorite. In the fluoritequartz-sulfide deposits various sulfide minerals occur as small irregular masses, lenses, and finegrained aggregates. The predominarit sulfide minerals are galena, sphalerite, pyrite, chalcopyrite, but minor quantities of enargite and tennantite are present locally. Clay minerals, carbonates, quartz, and opal are common gangue minerals.
In summary, uraniferous fluorite is found in many geologic environments in the western States. Pitchblende or uraninite has been reported only from the fluorite-sulfide deposits at Jamestown, Colo., and the Black Dike claims, Yuma, Ariz. In both localities dark-purple fluorite is associated with the uranium minerals. At 10 of the 18 known radioactive fluorite deposits, secondary uranium minerals are associated with dark-purple to black fluorite. At 6 of these localities the form in which the uranium occurs is unknown. In general it would appear that dark-purple to black fluorite is a favorable indication of the presence of radioactivity, and wherever dark fluorite is discovered radiometric studies and sampling for uranium should be undertaken. 


\title{
SECONDARY URANIUM DEPOSITS IN THE UNITED STATES
}

\author{
By Frederick Stugard, Jr., Donald G. Wyant, and Arthur J. Gude 3d
}

\section{ABSTRAC'T}

Reconstituted, or secondary, uranium minerals found in domestic deposits include oxides, phosphates, silicates, vanadates, arsenates, sulfates, and carbonates. Next to the vanadates carnotite and tyuyamunite, the most abundant are the phosphates autunite and torbernite and the silicate uranophane. Less common secondary uranium minerals are the oxides "gummite" and pitchblende; the phosphates dumontite and uranocircite; the silicates kasolite, skodowskite, and soddeite; the arsenates zeunerite and uranospinite; the sulfates zippeite, uraconite, and johannite; and the carbonate schroeckingerite. Other secondary minerals, in general, are only of mineralogic interest.

Many secondary uranium mineral deposits. show no obvious relation to known primary uranium minerals. The deposits now being mined at Marysvale, Utah, however, are surface expressions of pitchblende-bearing deposits. Recent studies indicate that formation of secondary minerals has in some places resulted in concentration and elsewhere in dispersion of uranium. Concentrations from ground water have formed extensive deposits of schroeckingerite in Sweetwater County, Wyo.

Many uranium compounds appear to be highly soluble and mobile. Successful distinction between secondary deposits resulting from concentration and those resulting from dispersion of primary deposits has not generally been made to date. Some sooty pitchblende is secondary.

Investigations by the Geological Survey on behalf of the Atomic Energy Commission have brought together considerable information on the mineralogy, distribution, and occurrence of secondary uranium deposits in the United States. Nevertheless, comparatively little is known on these subjects. Use of genetic designations such as "hypogene" and "supergene" does not yet seem practicable. We have designated as secondary minerals those derived from previously deposited uranium minerals. Under this definition, minerals formed as a part of original vein fillings are considered primary minerals.

Secondary uranium minerals occur in small quantity in many metallic veins, pyrometasomatic deposits, altered zones of volcanic rocks, sedimentary rocks, and pegmatites. In rare instances, secondary uranium minerals are sufficiently abundant to be economic sources of uranium, but elsewhere one of their main values is as possible indicators of associated primary ore.

More than 60 uranium minerals commonly of secondary origin have been listed (George, 1949; Frondel and Fleischer, 1950). If varietal names and uranium-proxy minerals be included, the list grows to more than 300 . Species previously recorded only from foreign localities are being discovered in almost every new deposit studied. Mineralogic work on this group is often difficult because of the intimate mixtures and variable water content that characterize these assemblages, and because of similarities among species of physical, optical, and chemical properties. Definite field identification of individual minerals is commonly impossible; often it must be changed after laboratory study.
Secondary deposits include uranium chemically combined as vanadates, phosphates, silicates, arsenates, sulfates, carbonates, and oxides. Almost every deposit includes several of these groups. Figure 13 shows some of the minerals that are known and their chemical grouping.

In the United States the production of most of the uraniur.--and formerly that of the radium--has come from carnotite (the hydrous potassium-uranium vanadate) deposits in sandstone. Tyuyamunite is the calcium analogue of carnotite. The most ubiquitous of all uranium minerals probably are the phosphates autunite and torbernite, and their "meta" forms. Dumontite and uranocircite are less abundant phosphates. The most common uranium silicate is uranophane, which usually occurs as fracture coatings in igneous and sedimentary rocks. Less common silicates include kasolite, sklodowskite, and soddyite.

Uranium arsenates have been found in very few localities in the United States. Zeunerite has been collected from Majuba Hill, Nev., and the Clancey area, Montana. Uranospinite, the calcium-uranium arsenate, has been tentatively identified from the Honeycomb Hills of Utah.

Efflorescent uranium sulfates and carbonates occur in semiarid environments. Zippeite characteristically occurs as coatings on mine walls, carbonized wood, and gypsum, as in the Oyler mine near Fruita, Utah. Uraconite is possibly only a lower hydrate of zippeite and has been found on mine faces in Gilpin County, Colo., and in the Hillside mine, Arizona. Johannite, a hydrous copper-uranium sulfate, is associated with a large suite of secondary minerals 


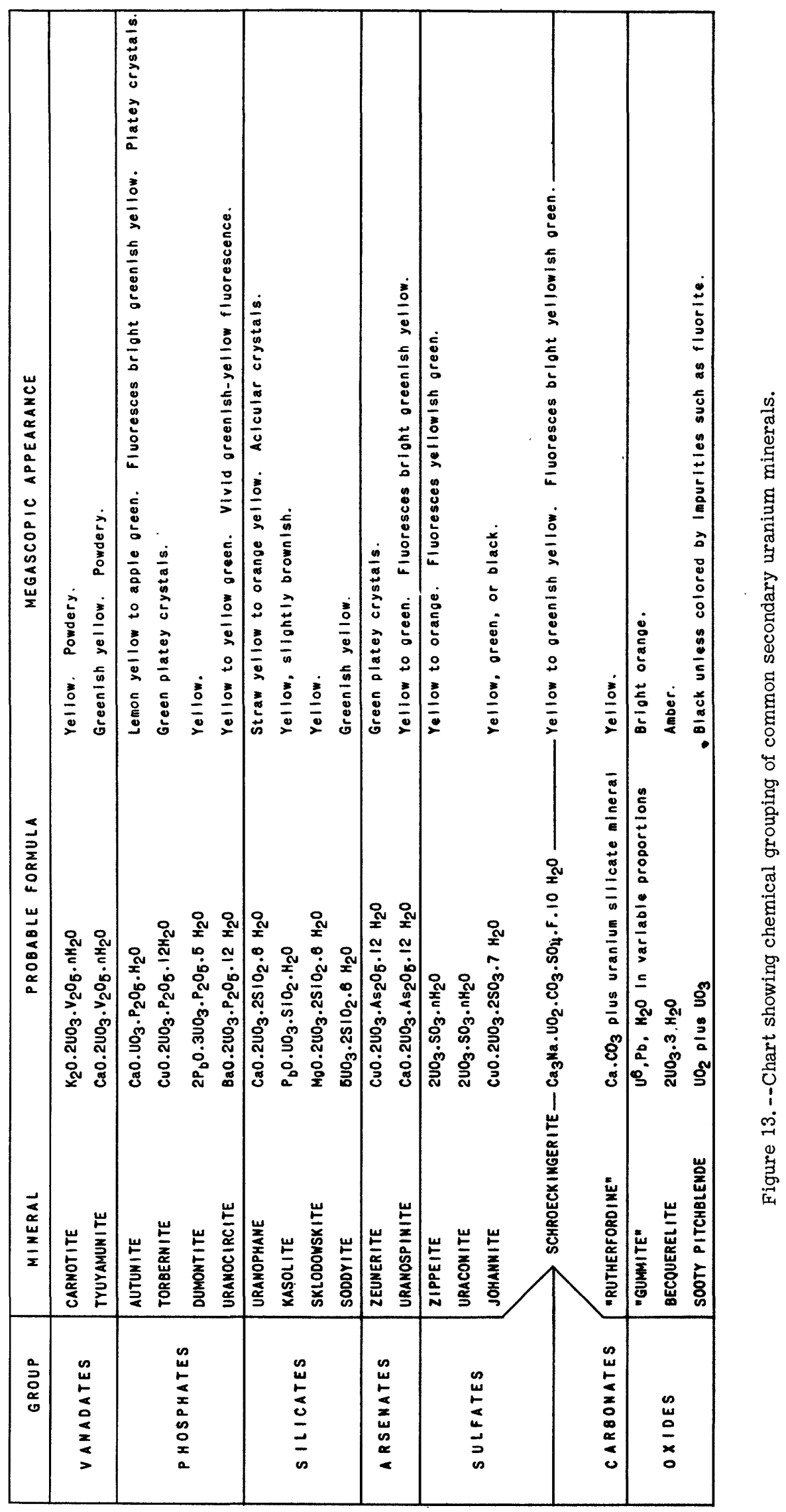


in the Happy Jack mine, San Juan County, Utah, and is also reported from Gilpin County, Colo. Schroeckingerite, the fluoro-sulfate and carbonate, occurs both in sedimentary rocks, as at Wamsutter, Wyo., and above vein structures, as at Marysvale, Utah, and the Hillside mine, Yavapai County, Ariz. "Rutherfordine" is intimately mixed with pitchblende and uranophane in veins of cryptocrystalline silica near Clancey, Mont.; much material previously called rutherfordine is now being reidentified as other uranium minerals with carbonate impurities. Three new carbonate minerals have recently been described by Axelrod and others (1951), and new discoveries are to be expected. As is evident from figure 13, numerous minerals appear very much alike to the naked eye.

The three most common secondary oxides of uranium are "gummite," becquerelite, and sooty pitchblende. Gummite is a common alteration product of uraninites in pegmatites and is easily recognized by its orange color; it does not have a valid formula. Some becquerelite and sooty pitchblende are redeposited forms of primary hard pitchblende.

An understanding of the distribution of secondary minerals in uranium deposits is essential to evaluation of the economic possibilities for most mines and prospects. Fragmentary information indicates that during the weathering and alteration of primary uranium deposits, different secondary uranium minerals form in different zones. The minerals formed vary with the composition of the vein and country rock, and the solutions formed by weathering. Figure 14 shows the general zonation of secondary uranium minerals in weathered veins. The diagram is a composite of available data from numerous deposits in sedimentary and igneous rocks.

As shown in the right-hand column, a vein containing primary uranium oxides, with the necessary accessory metals, would be altered under favorable conditions of weathering to yield a secondary deposit capped by a zone of efflorescent uranium sulfates and carbonates. This zone may be expected to grade downward into a zone containing uranium silicates, phosphates, arsenates, or vanadates; the assemblage that is developed depends upon the composition of the solutions causing the alteration. This assemblage grades downward into a zone of secondary uranium oxides, accompanied by relict primary uranium oxides. Below this is the zone of unaltered primary oxides.

The deposit of secondary minerals is shown in figure 14 as widening upward, spreading laterally along fractures. This lateral migration may result in an over-all dispersion of the uranium from the vein. In places,such as Marysvale, Utah, these deposits are sufficiently rich to form a minable ore body.

Marysvale is the best-known domestic area to date that has economic deposits of both primary and secondary minerals in the same altered vein structures. Investigations of operating mines in the district, currently in progress by the Atomic Energy Commission, are expected to yield much information on the relationships of primary to secondary minerals.

Weathering of veins containing pitchblende, quartz, fluorite, pyrite, and other sulfides at Marys- vale has produced the typical zonation of uranium minerals, as shown in figure 14. At the surface, schroeckingerite is associated with uranophane, autunite, and torbernite; this assemblage grades downward into a zone in which uranophane is the dominant mineral. Autunite and torbernite become relatively abundant in the lower parts of this zone and grade into a zone containing sooty pitchblende and relict masses of primary pitchblende.

The diagram showing zonation of secondary minerals in veins may be considered a mnemonic device. If figure 14 be turned on its side so that the surface represents a vertical cliff face, it will represent essentially the sequence of minerals found in sedimentary deposits inward from a leached outcrop, as for example at the Happy Jack mine, San Juan County, Utah. The surface exposure of this ore body contains efflorescent salts, such as johannite and chalcanthite. Uranophane and torbernite appear within a short distance and increase in abundance inward toward a deposit containing pitchblende, pyrite, chalcopyrite, chalcocite, and gersdorffite.

In contrast to the example just given, some actual vein-type deposits do not appear in the field to look much like the idealized diagram. In the Marysvale area, at East Slope no. 2 deposit (fig. 15), secondary uranium minerals are associated with alunitic and clay alteration zones in a veinlike structure within hornfels. Autunite, metatorbernite, schroeckingerite, and uranophane are distributed along the face of the open-cut in two main zones, roughly symmetrical about a core of hematite-alunitequartz-kaolinite rock. The uranium minerals coat fractures and joints in the altered hornfels. It is not known whether this deposit is transitional downward into other depth zones of the typical vein structure.

Secondary uranium vanadates and arsenates occur in vein structures at several places. For example, tyuyamunite is found in fractured quartzite at the Yellow Canary claims, Daggett County, Utah, and carnotite in the fluorite deposits of the Thomas Range district, Utah. Zeunerite is associated with torbernite at Majuba Hill, Nev., and Clancey, Mont. These localities, together with the others mentioned in this report, are shown in figure 16.

Many pegmatites contain gummite, autunite, and other minerals as halos around primary uranium minerals. Pegmatite localities are not shown on figure 16.

Lignites in North and South Dakota, Montana, and Wyoming, contain a hydrous uranium oxide, probably becquerelite. Some uranium oxides associated with organic minerals found in stratigraphically controlled deposits have secondary characteristics.

Interesting comparisons might be made between the secondary uranium minerals found in the United States that may lead to primary ore as the deposits are developed, and the secondary uranium. minerals accompanying the great deposits being mined in Canada and the Belgian Congo. Many descriptions of these foreign localities, however, make little mention of the secondary minerals. One of the few good illustrations of secondary minerals accompaning primary uranium oxide is that given by Thoreau and Terdonck (1933), adapted here as figure 17. 


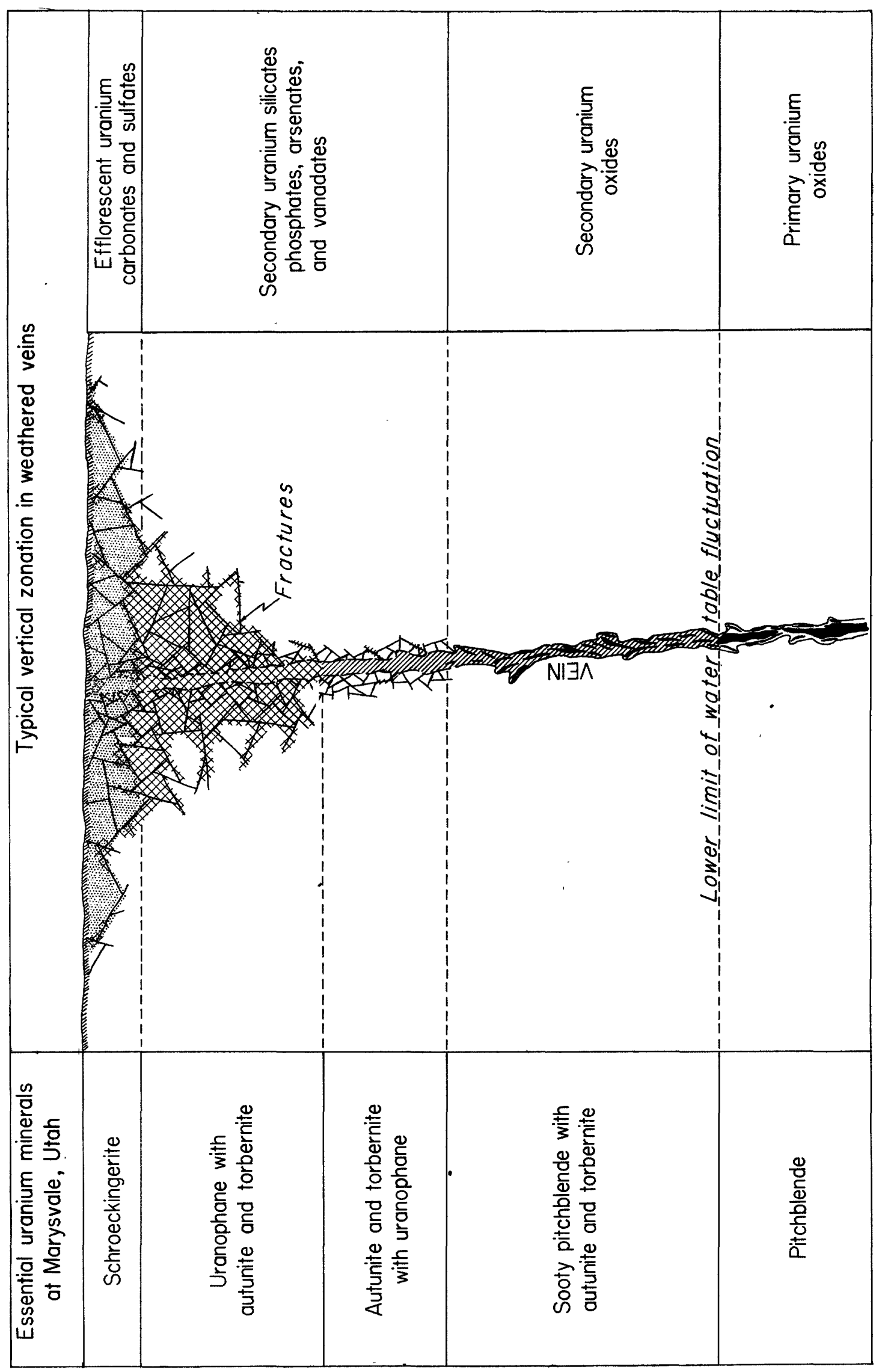

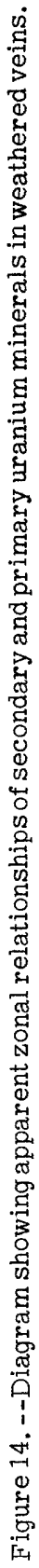



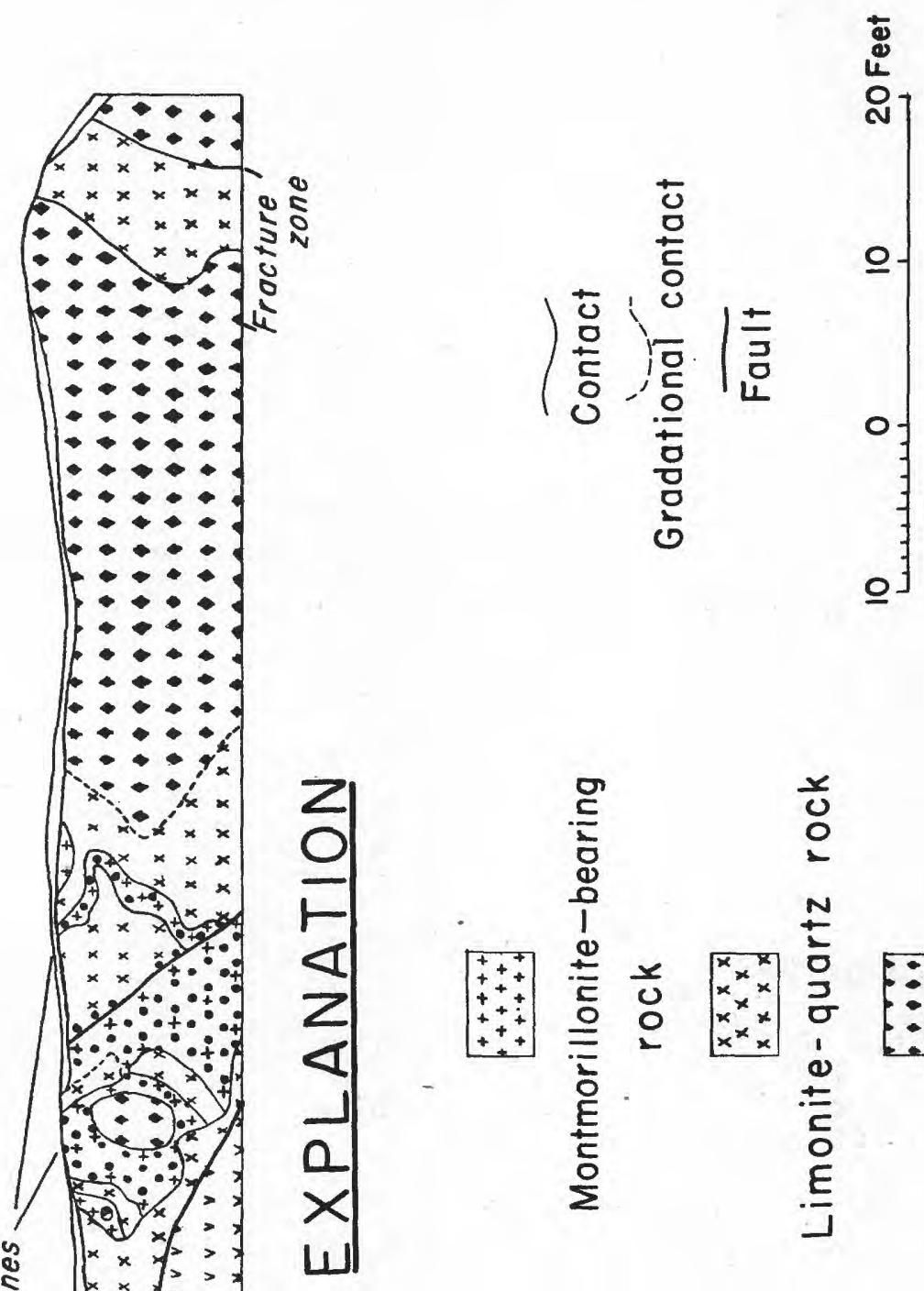

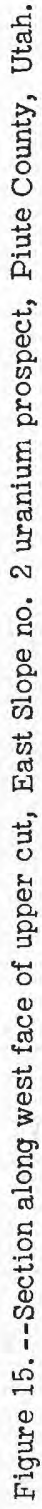
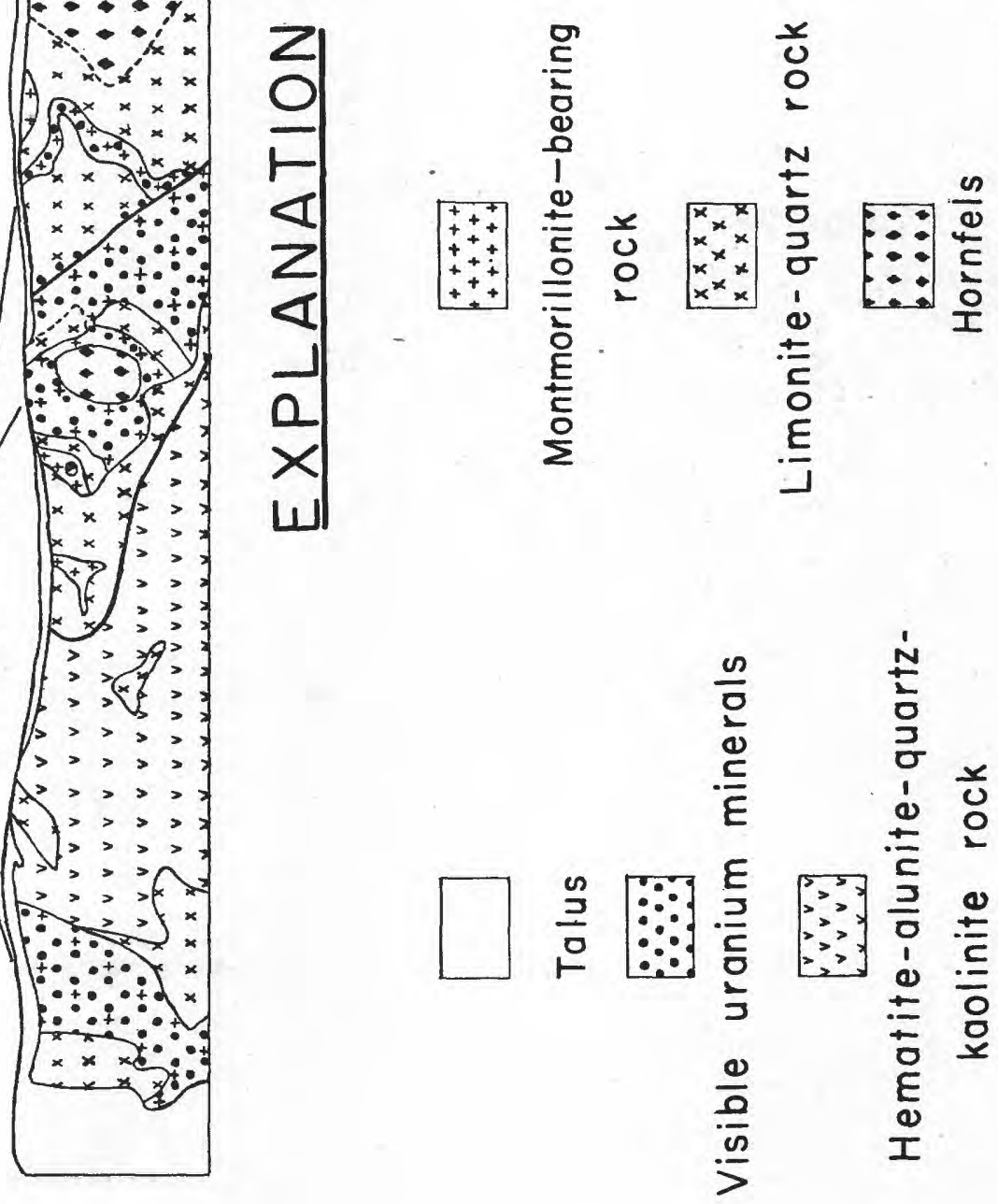


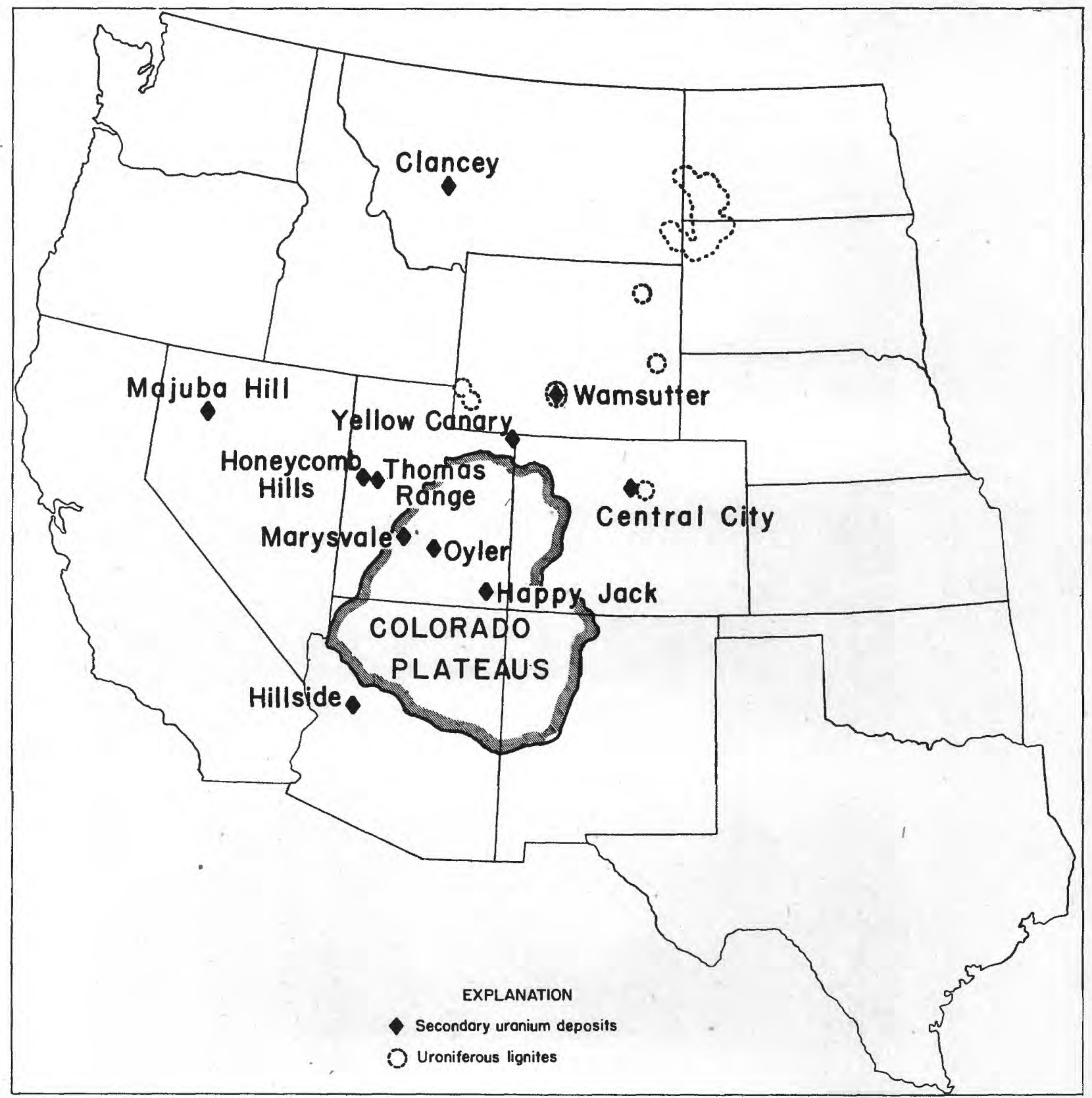

Figure 16. --Map showing location of secondary uranium deposits. 


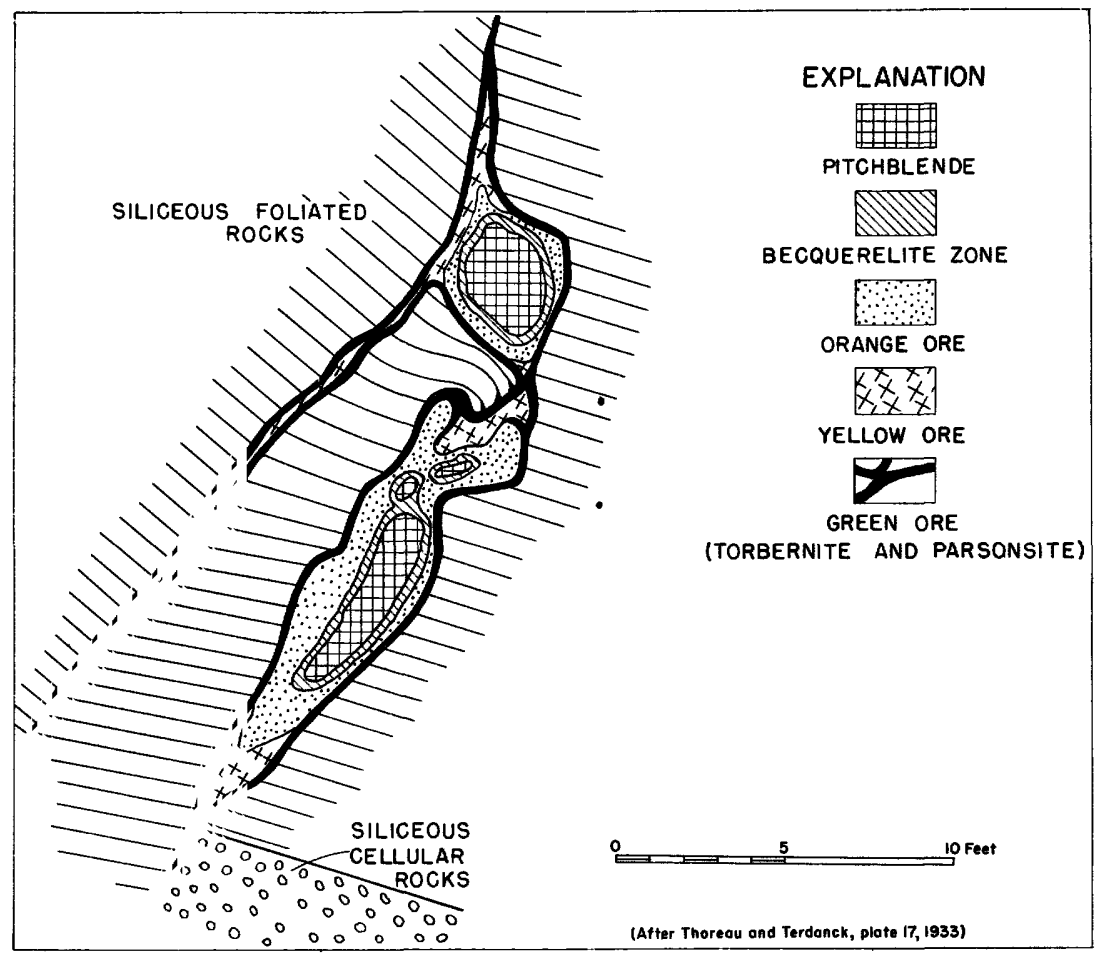

Figure 17. --Vertical section across a vein, Shinkolobwe, Belgian Congo

Around the pitchblende is a halo of becquerelite. This in turn is surrounded by an orange zone composed of curite (a uraniferous hydrate of lead), mixed with kasolite, soddyite, and uranophane. The yellow ore beyond that is schoepite (a hydrated oxide of uranium), together with the silicates soddyite or uranophane. The outside part of the vein is composed of torbernite and parsonite (hydrated phosphates). Thus, from the inside to outside the mineral assemblage is: oxides, hydrates of lead and uranium, silicates, phosphates. All the secondary minerals have been derived apparently from the primary vein pitchblende. The small-scale zoning apparent here may be represented on a large scale by zones of secondary uranium minerals above primary deposits in the United States.

In conclusion, secondary uranium minerals form under a great variety of conditions. It is clear that uranium possesses great mobility in some form at surface temperatures. The often-observed presence of fluorite suggests that, in some deposits at least, dilute hydrofluoric acid solutions from the fluorite may form complex uranium fluorides that are readily soluble in cold water and adsorbed in silica gel. Abundant iron staining in most deposits suggests that uranium is distributed in much the same manner as ferrous or ferric iron during the weathering cycle. It is also known (Rankama and Sahama, 1950, p. 636) that uranium compounds are adsorbed on iron hydroxide gel and silica gel. The size and mineralogy of secondary deposits are systematically related to the original bulk chemical composition and the erosional environment.

\section{LITERATURE CITED}

Axelrod, J. M., Grimaldi, F. S., Milton, Charles, and Murata, K. J., 1951, The uranium minerals from the Hillside mine, Yavapai County, Ariz. : Am. Mineralogist, vol. 36, pp. 1-22.

Frondel, J. W., and Fleischer, Michael, 1950, A glossary of uranium- and thorium-bearing minerals: U. S. Geol. Survey Circ. 74.

George,d'Arcy, 1949, Mineralogy of uranium and thorium bearing minerals: U. S. Atomic Energy Comm., RMO-563, rev. ed., Tech. Inf. Service, Oak Ridge, Tenn.

Rankama, Kalvero, and Sahama, T. G., 1950, Geochemistry [Chicago], Univ. Chicago Press.

Thoreau, J., and du Trieu de Terdonck, R., 1933, Le gite d'uranium de Shinkolobwe-Kasolo (Katanga): Inst. royal colonial belge, Sec. Sci. nat. et méd., Mém., tome 2, fasc. 1 , pl. 17 . 


\title{
SOME URANIUM DEPOSITS IN SANDSTONES
}

\author{
By Donald G. Wyant, Ernest P. Beroni, and Harry C. Granger
}

\section{ABSTRACT}

The uranium deposits in sandstone of the Jurassic Morrison and Entrada formations of the Colorado Plateaus are relatively well known and have long been the principal sources of domestic uranium and vanadium. Not so well known are uranium deposits in other sandstones that range in age from Paleozoic to Recent.

Of the uranium deposits in sandstone, some are of the type common to the Colorado Plateaus, but many others differ from this type in mineralogy, host rock, localization, and possible origin. The deposits may be grouped on the basis of mineral or metal assemblage into (1) uranium-vanadium deposits; (2) copper-uranium-vanadium-carbonized wood deposits; (3) uraniferous asphalt deposits; and (4) miscellaneous deposits including carbonate deposits.

In general these deposits occur in lenses of argillaceous sandstone or conglomerate interbedded with shales. Common associated materials are iron oxide, carbon, and copper compounds. The localization of some of these deposits appears to be controlled by initial sedimentary features of the enclosing rock, that of others by porosity, fractures, and proximity to the surface. Some of the uranium minerals may have been deposited from ground water, some may have formed by weathering and oxidation of other minerals, and some may be hydrothermal in origin.

The carnotite and roscoelite deposits in sandstones of the Morrison and Entrada formations of Jurassic age have long been the principal domestic sources of uranium and vanadium. Descriptions of many of these deposits on the Colorado Plateaus have been published, and the deposits are relatively well known. Not so well known are uraniur. deposits in other sandstones that range in age from Paleozoic to Recent.

It is the purpose of this paper to point out the geographic and geologic distribution of uranium deposits in sandstones, some of their characteristics, similarities, and differences. Much of the data on which this paper is based has been collected during work on uranium deposits by the U. S. Geological Survey on behalf of the Atomic Energy Commission.

Uranium minerals found in lenses of porous terrestial sandstones containing shale fragments or pellets, or in conglomerates interbedded with shales, are commonly associated with vanadium, carbon, copper, and iron oxide.

On the basis of these associations the uranium deposits in sandstones may be grouped into four main types: (1) uranium-vanadium deposits; (2) copperuranium-vanadium-carbonized wood deposits; (3) uraniferous asphalt deposits; and (4) miscellaneous deposits, including the caliche-type carbonates and deposits in tuffs. Nearly all these deposits have resulted probably from epigenetic processes, although their geologic history is incompletely known; in any event, the uranium appears to have been redistributed by ground water in many of them.

The best-known uranium-vanadium deposits are the stratigraphically controlled carnotite deposits in the Salt Wash sandstone member of the Morrison forma- tion in the Colorado Plateaus. Similar deposits include those in the Morrison formation northeast of Meeker, Colo. (fig. 18), and the roscoelite deposits in the Entrada formation near Rifle and Placerville, Colo. These deposits have been adequately described by Fischer (1942) and others. According to McKeown (1949) and Butler and Bush (1951), usanium-vanadium deposits also occur near Mauch Chur.k, Pa. (fig. 18), with thin stratigraphic units in sandstones of the Pottsville formation of Pennsylvanian age and in Willards Cherry Ridge red beds of Upper Devonian age. Here the uranium has been redistributed by ground water.

Fractures and related faults control the localization of the uranium minerals in sandstone of the Morrison formation at the Mike Doy'e prospect (Beroni and King, 1950), in sandstone of the Kaibab limestone of Permian age at Goodsprings, Nev. (Hewett, 1923), and in limestone of the Laramie formation of Cretaceous age at the Leyden coal mine (Gott, 1950; McKeown and Gude, 1951).

A second type of uraniferous deposit found in sandstone includes those deposits containing copper, uranium, vanadium, and carbonized wood. They are found in sandstones of Permian to Eocene age. Other elements commonly present in these deposits include silver, cobalt, iron, sulphur, selenium, and carbon. In some, carnotite is the principal mineral, but in others, uraniferous carbonized wood or copper minerals predominate. Uranium oxide, probably pitchblende, has been found in a few.

Several deposits of this type resemble the carnotite deposits of the Colorado Plateaus in apparent lack of structural control and in vanadium content. Examples are the Silver Reef deposits, Utah (fig. 18), and the deposits at Skull Creek and Garo, Colo. 


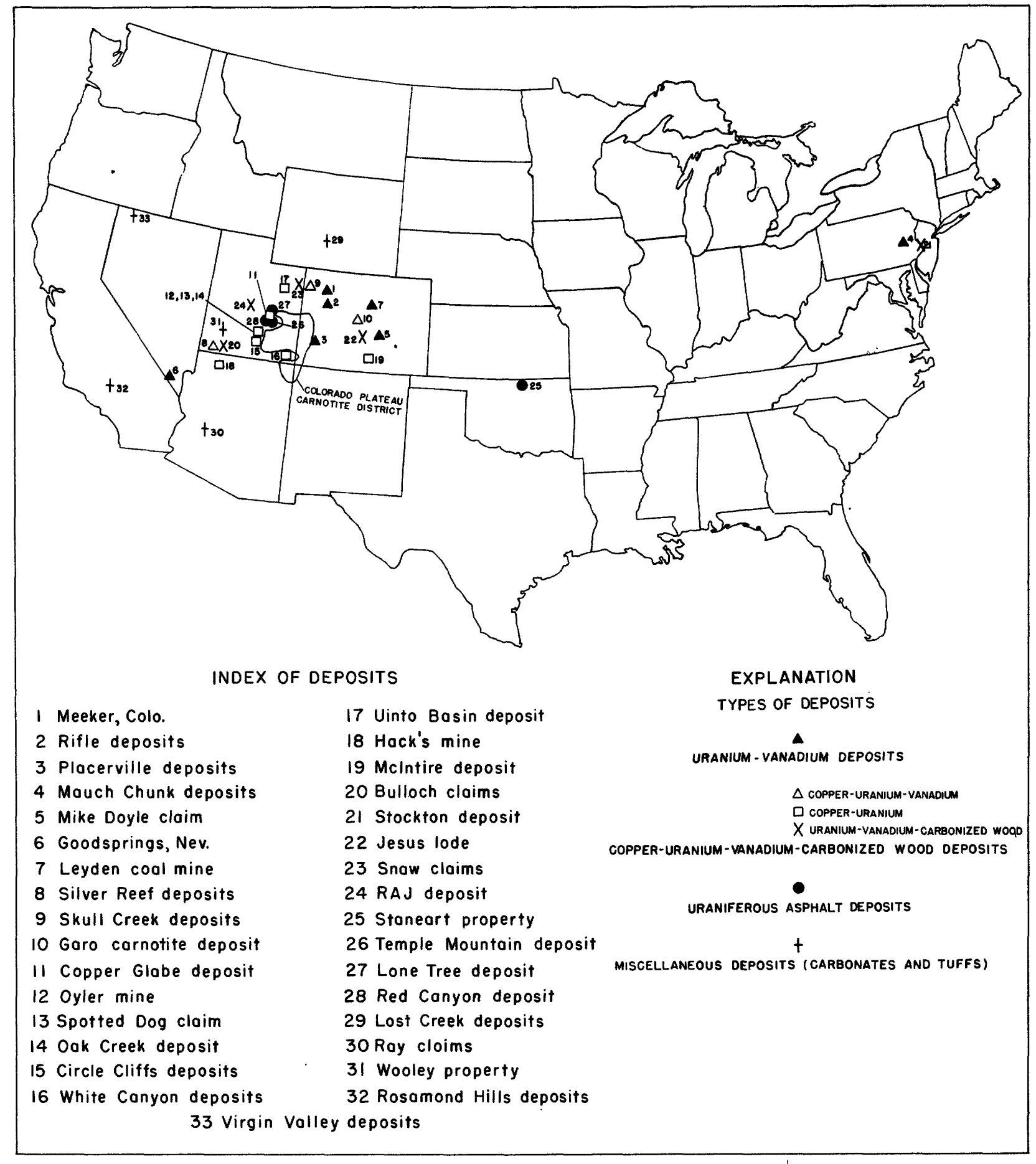

Figure 18. --Index map of some uranium deposits in sandstones. 
(fig. 18), reported by Gott, 1951. In the Silver Reef deposits, carnotite, volborthite (a basic copper vanadate), and an unidentified uranium mineral are associated with cerargyrite (silver chloride), carbonized plant remains, and copper carbonates. In addition selenium is uncommonly abundant. The deposits are in irregular lenses of sandstone containing clay pellets. These lenses are part of the Chinle formation of Triassic age. Carnotite and volborthite are found associated with uraniferous carbonaceous shale and carbonized plant fossils at Skull Creek and Garo, Colo. These deposits are in shale and sandstone in the upper part of the Jurassic Navajo sandstone, and in sandstones of the Permian and Pennsylvanian Maroon formation.

The most economically important subdivision of the second general type is the copper-uranium deposits, which contain little or no vanadium. These deposits have been found in sandstones from Permian and Pennsylvanian to Eocene age, but are particularly abundant in the Triassic Shinarump conglomerate on the Colorado Plateaus. The known deposits of this subdivision are in southwestern Utah (fig. 18) (Wyant and others, 1950; Granger and Beroni, 1950; Granger and Bauer, 1950); in Hack's Canyon, Ariz. (fig. 18), according to Dunning (1948); and in the McIntire prospect in Huerfano Park, Colo.

In the Huerfano Park district, and in some of the deposits in the Circle Cliffs area (fig. 18), carnotite, carbonized wood, and radioactive iron oxide are the dominant uranium-bearing materials, but at the Copper Globe, Spotted Dog, Oak Creek, and Uinta Basin deposits (fig. 18) torbernite and uraniferous carbonized plant fragments are the common uranium-bearing materials. In the Oyler mine, in White Canyon, Utah, and in the Hack's mine, Arizona, several hydrous uranium oxides, phosphates, and sulfates are abundant near the surface. In the Happy Jack mine in the White Canyon area (fig. 18) the deposit grades laterally from secondary carbonates and sulfates at the exposed cliff face to sulfides and pitchblende in the mine workings about 75 feet underground.

At the Oyler mine near Fruita, Utah (figs. 18 and 19), zippeite, torbernite, and other secondary uranium minerals, together with highly uraniferous carbonized wood and hydrocarbons, are associated with copper sulfates and carbonates in podlike lenses at the base of the Shinarump conglomerate. Samples from the mine workings contain from 1.50 to 4.00 percent equivalent uranium and from 0.33 to 1.22 percent uranium. The excess radioactivity is caused by radium, and calculations suggest that the fresh, unweathered ore might have contained as much as 6.8 percent uranium. These high-grade ore bodies are at the base of the Shinarump conglomerate in zones that represent local irregularities of ancient stream channels. Within these channels, individual ore bodies are localized by small primary sedimentary structures that resemble monoclinal folds or synclines. Below the ore zones, the gray-green altered Moenkopi shale is highly calcareous.

Deposits of this subdivision probably represent the weathered part of primary bodies.

Another subdivision of the copper-uranium-vanadium-carbonized wood deposits is that in which the deposits contain little or no copper. Deposits of this type are found in Triassic, Jurassic, and Eocene sandstones in New Jersey, Colorado, and Utah. At the Bulloch claims near Orderville, Utah (fig. 18), Beroni and others (1951) report that carnotite, autunite,

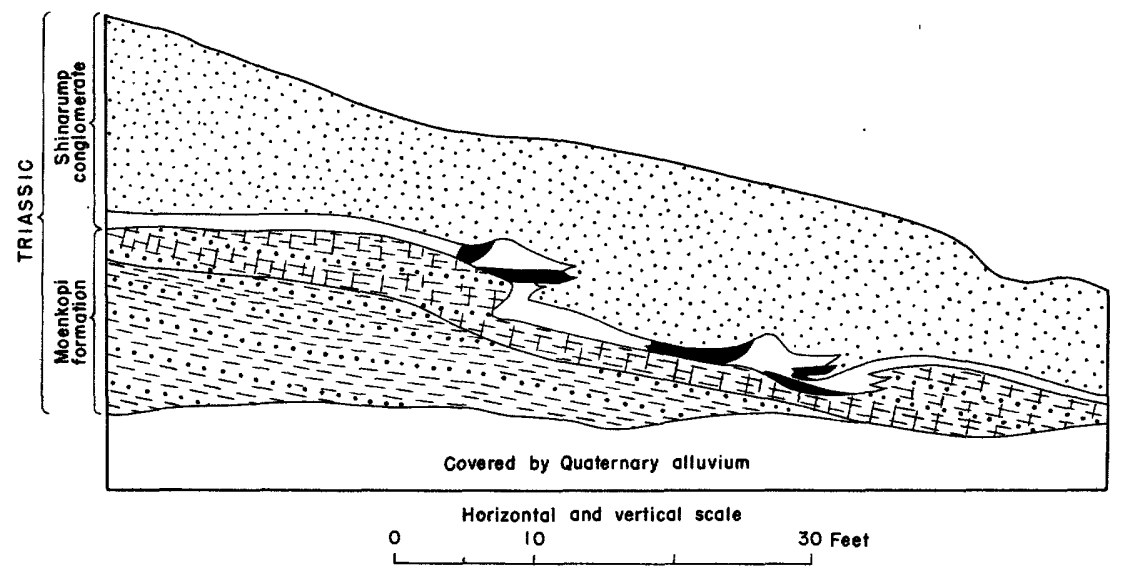

EXPLANATION
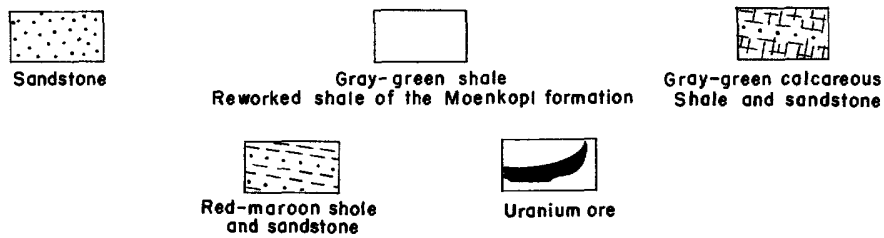

Figure 19.--Section of cliff face, Oyler mine, Wayne County, Utah 
torbernite, and uraniferous carbonized wood are disseminated or coat pebbles and fracture surfaces in the sandstones of the Cretaceous Dakota and Jurassic Summerville formations. In New Jersey (fig. 18) torbernite occurs in arkoses of the Triassic Stockton formation. Torbernite, or autunite, and uraniferous carbonized wood are present in Cretaceous Dakota sandstone at the Jesus lode (fig. 18), in Cretaceous Mesa Verde sandstone on the Snow claims (fig. 18), and in the Eocene Green River formation at the RAJ prospect (fig. 18).

The uraniferous asphalt deposits are a third major type of uranium deposits in sandstone. They have been found in Permian sandstone at the Staneart property in Oklahoma (fig. 18) and in Triassic sandstones and conglomerates of the Shinarump and Chinle formations at the Temple Mountain, Lone Tree, and Red Canyon deposits in the San Rafael Swell, Utah (fig. 18).

In the Temple Mountain district, Utah (figs. 18 and 20), uraniferous asphaltite occurs as void fillings, rounded pellets, veinlike fillings, and as detrital grains in friable sandstone lenses of the Shinarump conglomerate. Carnotite, zippeite, and other secondary uranium and vanadium minerals coat asphaltite grains. Carnotite also occurs in "rolls" in sandstone that resemble the rolls described in the Morrison carnotite bodies. The asphaltite ore bodies are localized in sandstones that fill ancient stream channels. The carnotite in this district appears to have been derived from the asphalt. The asphalt in all these deposits may be the mineraloid thucholite. Similar highly radioactive pellets have been found in the Oyler mine, the Oak Creek prospect, and at the Four Aces mine in the White Canyon area, Utah (fig. 18).

A fourth general type of uranium deposits in sandstone includes caliche-type carbonate deposits, uranium deposits in waterlaid tuffs and placers, and other miscellaneous deposits. Schroeckingerite at Lost Creek, Wyo. (fig. 18), is in rounded pellets in Eocene Green River shale or in flakes in the enclosing Eocene silts and arkoses (Page, 1950; Wyant and Sheridan, 1951). Schroeckingerite has been found to depths of 8 feet beneath the surface, but always above the ground-water table. The mineral has been deposited as an evaporite. So far as known, it is limited to a zone of faulting and overlies uraniferous lignite.

Uranium minerals have been described from samples of Tertiary tuffs near Aquila, Ariz. (Hewett, 1925), and from the Wooley prospect in Utah, from Rosamond Hills, Calif. (Chace, 1950), andfrom Virgin Valley (Staatz and Bauer, 1951). (See fig. 18.) Carnotite, autunite, uraniferous opal, and probably schroeckingerite are the uranium minerals.

Resistant rare-earth thorium minerals containing a little uranium are found in some placer deposits. We know of no deposits containing placer pitchblende.

The origin and genesis of the uranium deposits in sandstones is still an open question. Ground water has played an important role in all of them, either by redistributing uranium from the primary concealed deposits, or by introducing uranium from outside sources. The localization of some of the deposits is controlled by fractures, that of others by porous sandstone. In some, a retation to petroleum seems evident. Many may have haa a hydrothermal origin. More must be known about uranium deposits in sandstones before a comprehensive explanation of their origin and distribution can be made.

\section{LITERATURE CITED}

Beroni, E. P., and King, R. U., 1950, The Mike Doyle carnotite deposit, El Paso County, Colo.: U. S. Geol. Survey Trace Elements Mem. Rept. 133. [Open files.]

Beroni, E. P., McKeown, F. A., Stugard, Frederick, Jr., and Gott, G. B., 1951, Uranium deposits on the Bulloch group of claims, Kane County, Utah: U. S. Geol. Survey Trace Elements Mem. Rept. 213. [Unpublished.]

Butler, A. P., Jr., and Bush, A. L., 1951, Inspection of carnotite deposits near Mauch Chunk, Carbon County, Pa.: U. S. Geol. Survey Trace Elements Mem. Rept. 241. [Unpublished.]

Chace, F. M. , 1950, An autunite deposit in the Rosamond Hills, Kern County, Calif.: U. S. Geol. Survey Trace Elements Mem. Rept. 136. [Unpublished.]

Dunning, C. H., 1948, Report on Hack's Canyon uranium mine: Arizona Dept. Mineral Resources. [Unpublished report. ]

Fischer, R. P., 1942, Vanadium deposits of Colorado and Utah, a preliminary report: U. S. Geol. Survey Bull. 936-P, pp. 363-394.

Gott, G. B., 1950, The Leyden uranium prospect, Jefferson County, Colo.: U. S. Geol. Survey Trace Elements Mem. Rept. 132. [Unpublished.]

1951, Garo uranium deposits, Park County, Colo.: U. S. Geol. Survey Trace Elements Mem. Rept. 222. [Unpublished.]

Granger, H. C., and Bauer, H. L., Jr., 1950, The Eureka and Happy Landing groups of claims, Uintah County, Utah: U. S. Geol. Survey Trace Elements Mem. Rept. 32. [Unpublished.]

Granger, H. C., and Beroni, E. P., 1950, Uranium occurrences in the White Canyon area, San Juan County, Utah: U. S. Geol. Survey Trace Elements Mem. Rept. 7. [ Unpublished. ]

Hewett, D. F., 1923, Carnotite in southern Nevada: Eng. and Min. Jour.-Press, vol. 115, no. 5, pp. 232235 .

1925, Carnotite discovered near Aguila, Ariz.: Eng. and Min. Jour-Press, vol. 120, no. 1, p. 19.

Mckeown, F. A., 1949, Preliminary report of uranium deposits near Mauch Chunk, Pa.: U. S. Geol. Survey Trace Elements Mem. Rept. 19. [Unpublished.]

McKeown, F. A., and Gude, A. J. 3d, 1951, Preliminary report on the carnotite deposits of the old Leyden coal mine, Jefferson County, Colo. : U. S. Geol. Survey Trace Elements Mem. Rept. 308. [Unpublished.]

Page, L. R., 1950, Interim report of geologic investigation, Lost Creek schroekingerite deposits, Sweetwater County, Wyo.: U. S. Geol. Survey Trace Elements Mem. Rept. 183. [Open file.]

Staatz, M. H., and Bauer, H. L., Jr., 1951, Virgin Valley opal district, Humboldt County, Nev.: U.S. Geol. Survey Circ. 142.

Wyant, D. G.; Stugard, Frederick, Jr. ; and Kaiser, E. P., 1950, Uranium resources in the Marysvale region, Utah, and interim report: U. S. Geol. Survey Trace Elements Mem. Rept. 169. [Unpublished.]

Wyant, D. F., and Sheridan, D. M., 1951, Interim report, Lost Creek schroekingerite deposit, Sweetwater County, Wyo.: U. S. Geol. Survey Trace Elements Mem. Rept. 244. [Unpublished.] 

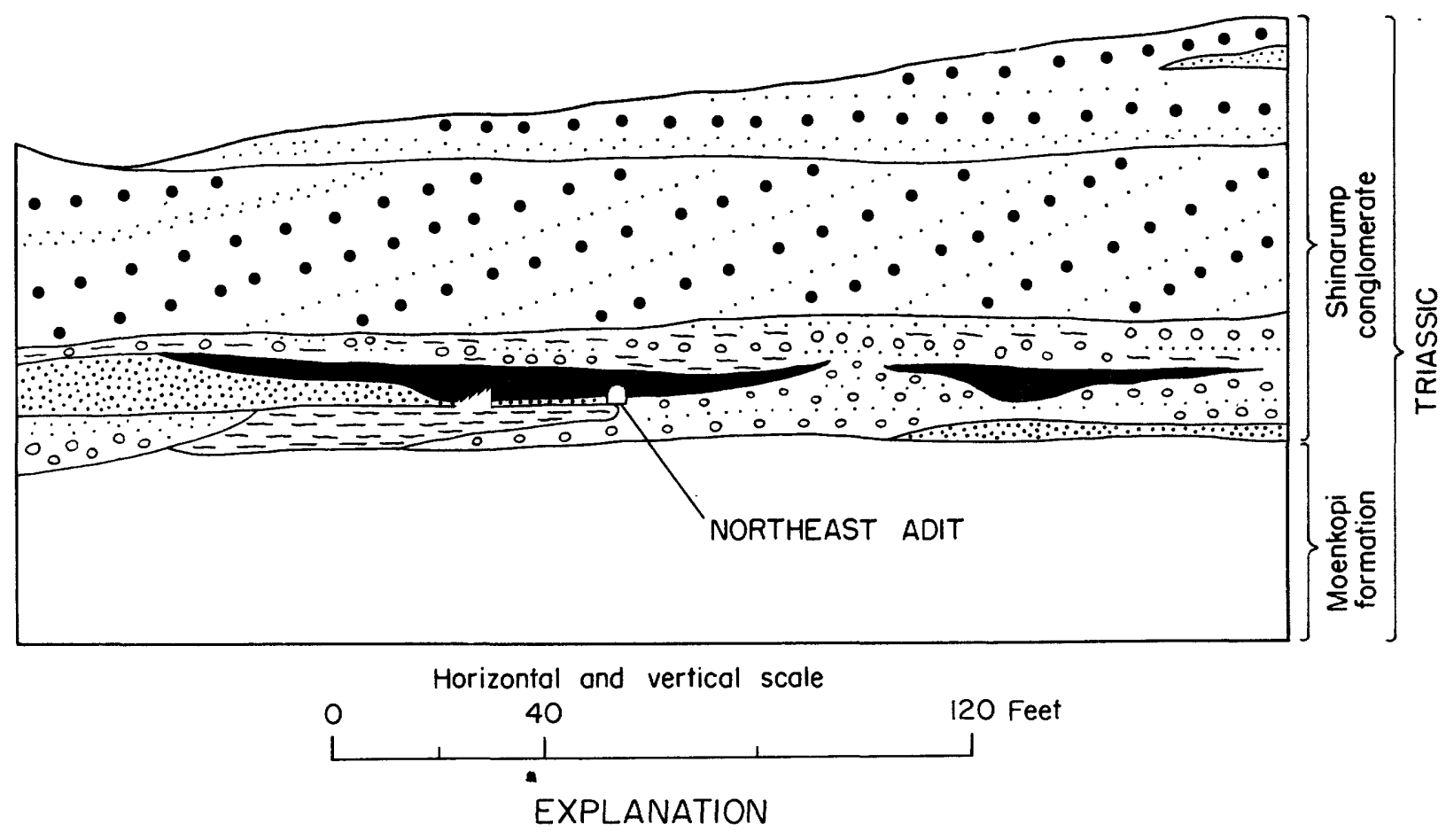

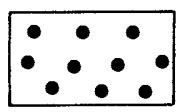

Lime-pellet conglomerate

$$
\begin{array}{|lllll}
0 & 0 & 0 & 0 & 0 \\
0 & 0 & 0 & 0 \\
0 & 0 & 0 & 0 \\
\hline
\end{array}
$$

Chert-pebble conglomerate

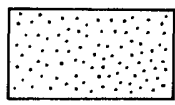

Sondstone

$$
\begin{array}{llll}
-1 & - & - & - \\
0 & 0 & 0 & 0 \\
\hline
\end{array}
$$

Mudstone and mudstone-gravel

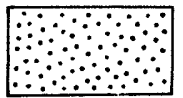

Bituminous sandstone

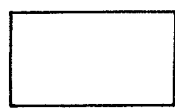

Groy-green shale

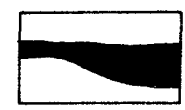

Uranium ore

Asphaltite grains in sandstone

Figure 20.--Cliff face, Shinarump Mesa, Temple Mountain district, Utah. 


\section{URANIUM IN BLACK SHALES, LIGNITES, AND LIMESTONES IN THE UNITED STATES}

By Garland B. Gott, Donald G. Wyant, and Ernest P. Beroni

\section{ABSTRACT}

Small quantities of uranium occur in carbonaceous deposits at a great many localities in the United States, but the amount rarely exceeds 0.1 percent. The most common uranium-bearing carbonaceous deposits are in the black marine shales, principally of Paleozoic age, exposed in the eastern and central parts of the United States. The uranium content of most of these shales ranges from a few thousandths to a little more than 0.01 percent.

Another type of low-grade uranium-bearing carbonaceous deposit is represented by some of the lignite deposits of Tertiary age in Montana, Nevada, North Dakota, South Dakota, and Wyoming. The uranium content of these uraniferous lignites is comparable to that of the black shales. The concentration of uranium in the lignite ash, however, is considerably greater than in the black shales.

Several widely distributed uranium deposits in limestone, most of which are low grade, have been discovered recently in Missouri, New Mexico, New Jersey, Utah, and Vermont. The limestones range in age from pre-Cambrian to Tertiary. In some of these deposits the uranium is associated with phosphatic, carbonaceous, or argillaceous material. In others, secondary uranium minerals occur as fillings in fractures and vugs.

Uraniferous black marine shales have been described by many investigators, but reference to uraniferous terrestrial shales, coals, and carbonate rocks are not common. Recent investigations by the U. S. Geological Survey, made on behalf of the Atomic Energy Commission, have indicated that such deposits are widespread in the United States.

Figure 21 shows the distribution of some of the uraniferous blackshales, coals, and limestones in the United States. Figure 22 shows, in more detail, the distribution of some of the better-known uraniferous marine carbonaceous shales. This type of shale is best represented by the Chattanooga shale of Devonian and Carboniferous age. It is best exposed in Tennessee and Kentucky, but its equivalents underlie much of the area between the Appalachian and Rocky Mountains.

The uranium content of the Chattanooga shale ranges between 0.001 and 0.03 percent. In general, the uranium content is greater in the more organic facies, although no direct ratio of uranium to organic material has been established. A few samples, consisting almost entirely of bitumen, contain more uranium than the enclosing shale. Analytical data suggest that there is a general correspondence between the uranium and the iron sulfide and vanadium content of the shale. The uranium is evenly distributed throughout the shale and apparently is inversely proportional to the carbonate and phosphate content.

Gamma-ray logs of oil wells in Kansas, Oklahoma, west Texas, and New Mexico indicate that the radioactivity of the Chattanooga shale, and its equivalent, the Woodford chert, is comparable to that exposed in the eastern United States.
Uranium content of the black Pennsylvanian shales in Kansas and Oklahoma is similar to that of the Chattanooga shale. Phosphatic nodules in these Pennsylvanian shales have a much higher uranium content than the clastic parts of the bed. Small quantities of thorium also are present in both the shale and the nodules. The blacker and more fissile phosphatic carbon-rich shales in this area contain the greater amounts of uranium.

Samples of carbonaceous marine shale of Pennsylvanian age from an oil well in east-central Wyoming contain from 0.005 to 0.02 percent uranium, which is comparable in grade to the Pennsylvanian carbonaceous shales of Kansas and Oklahoma and the Chattanooga shale in Tennessee and Kentucky. The oil content of the samples ranges from about 1 to $5 \frac{1}{2}$ percent.

The marine carbonaceous shales briefly discussed above are only some of many such shales in the United States. Other shales may be as radioactive or more radioactive than the Chattanooga and Pennsylvanian shales.

Uraniferous coals of Paleozoic, Mesozoic, and Tertiary ages are known in the United States. The greatest concentrations of uranium occur in Paleocene and Eocene lignites in the Dakotas, Montana, and Wyoming (fig. 23) and in a highash lignite in Nevada. A few bituminous Pennsylvanian coals in the midcontinent region and subbituminous Cretaceous coal in southwestern Wyoming contain as much as 0.004 percent uranium, but hundreds of others have been tested radiometrically and chemically with negative results. 


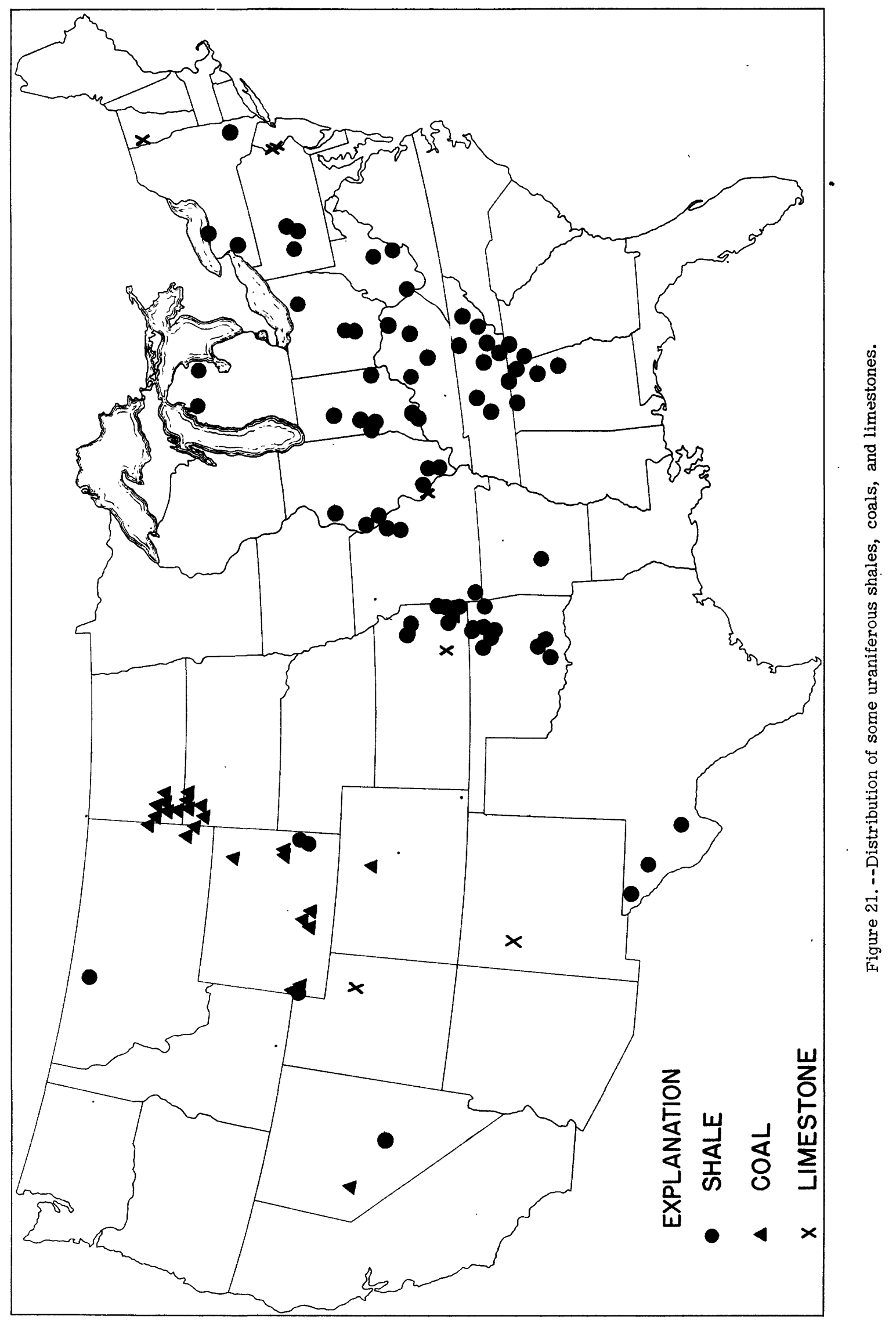




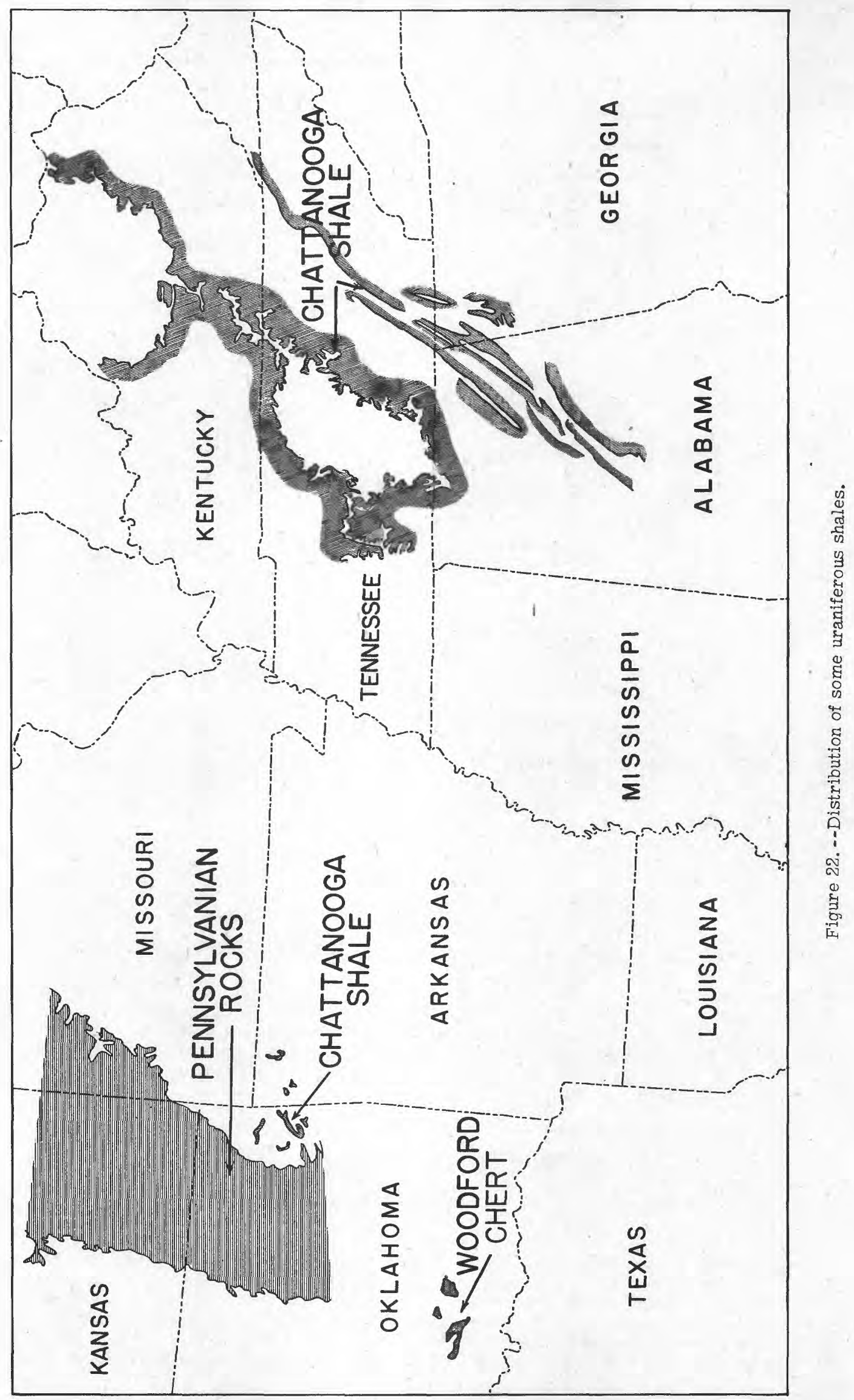




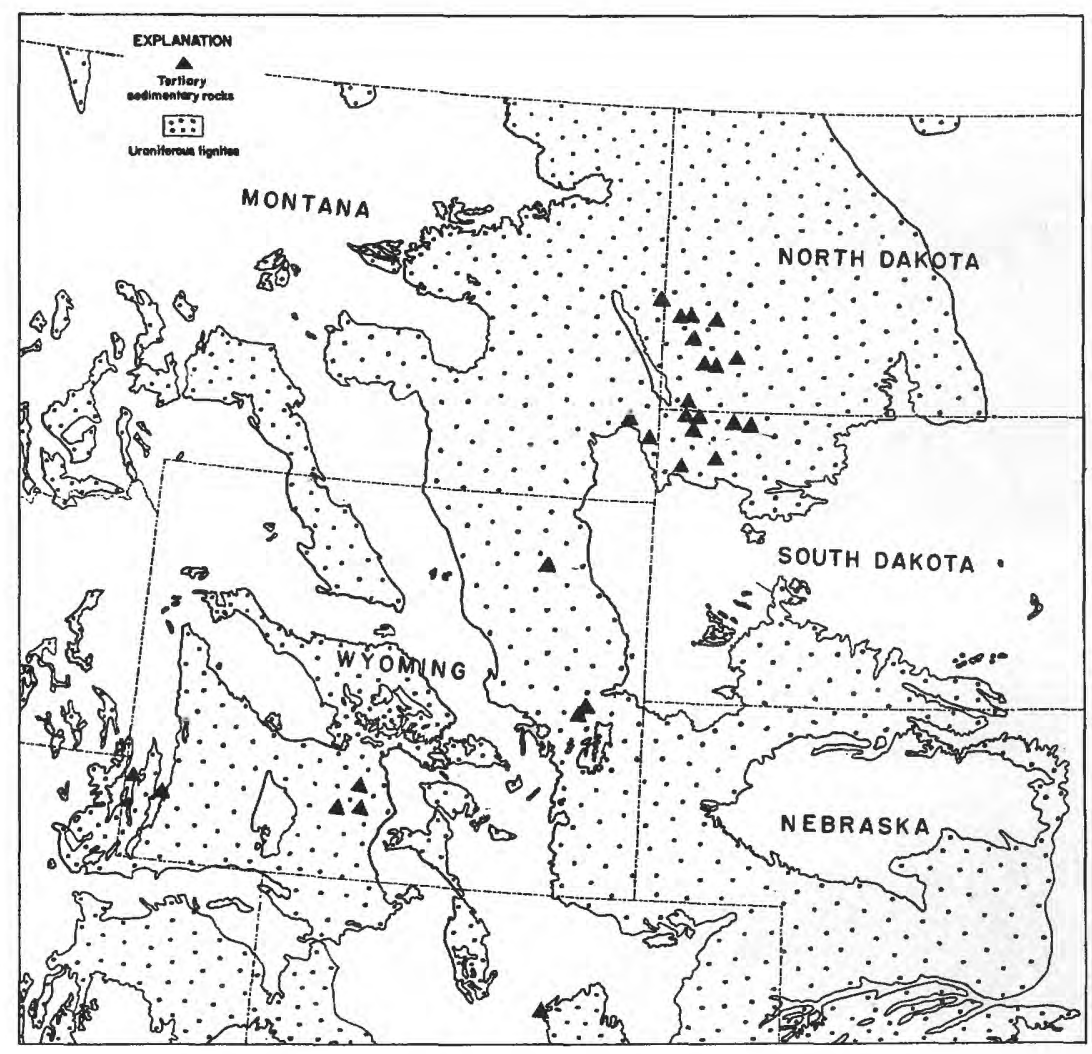

Figure 23. --Distribution of some uraniferous coals.

In the Dakotas, Montana, and part of Wyoming, the greatest concentrations of uranium occur in the first group of lignite beds below the Paleocene-Eocene unconformity. The uranium content of the lignite beds is variable, but some contain slightly more than 0.01 percent. The apparent relationship between these lignites and the unconformity between the Paleocene and the Eocene rocks suggest that the uranium may have been leached from volcanic ash in the White River formation and introduced into the lignite by surface waters during post-Paleocene time. The even distribution, however, of the uranium in the lignite, as indicated by an autoradiograph of one sample from North Dakota, and the absence of any apparent concentration of uranium on fracture planes in this area, suggest that the uranium was present before coalification.

In the Red Desert area of Wyoming uraniferous lignites in the Wasatch formation of Eocene age contain from about 0.002 to 0.007 percent uranium. The presence of about 60 percent more radium than that required for equilibrium with uranium indicates that uranium in the exposed lignite has recently been leached and suggests that fresh lignite contains more uranium.

A high-ash lignite of Tertiary age in Churchill County, Nev., contains as much as 0.05 percent uranium. The extremely high-ash content of this lignite, however, seems to preclude a significant concentration of uranium by burning such as can be effected with the other lignites mentioned.
The distribution of most of the uranium deposits that have been found in limestone or dolomite is shown in figure 21. Most of them are low in grade.

Uranium, possibly of syngenetic origin, has been found in a fresh-water limestone in the Uintah formation of Tertiary age in northeastern Utah, and in the Milton dolomite of Cambrian age in northwestern Vermont. The uranium in the Milton dolomite occurs in slightly petroliferous and phosphatic clay galls.

At Bussen's Quarry in Ste. Genevieve County, Mo., the Spergen limestone of Mississippian age contains finely disseminated detrital carbonaceous material and purple fluorite. Both the carbonaceous material and the fluorite contain uranium. The limestone encloses thin black shale beds that have been molded into stylolitic structures. The shale contains about 0.6 percent uranium, more than 100 times greater than in the average shales of the Chattanooga and Pennsylvanian type. Carnotite is sparsely distributed in the limestone adjacent to the black shale, and it is thought that the uranium in this mineral was leached from the black shale and transported by ground water.

The deposits near Grants, N. Mex., are in the Todilto limestone of Jurassic age. Uranium minerals are associated with hydrocarbon products and are localized by minor folds and fractures that may have been caused by intraformational slumping. Pitchblende, carnotite, tyuyamunite, and uranophane are associated with hematite, limonite, pyrite, and fluorite. 
Radium - and hydrocarbon-bearing dolomite and limestone of Ordovician and Pennsylvanian age are present in the subsurface of the North Augusta oil field in southeastern Kansas.

The concentration of uranium in organic marine shales has been the subject of considerable speculation, but the processes responsible for the accumulation have never been demonstrated. It has been variously suggested that the uranium was extracted from sea water by living organisms, that it was concentrated by colloidal adsorption, or that it was precipitated in the presence of a reducing agent. There seems to be supporting evidence for each of these hypotheses, but the common association of uranium with carbonaceous material suggests that the uranium was most probably concentrated originally by biochemical processes. The association of uranium with bituminous shales, asphaltic sandstones, and petroliferous limestones suggests that some crude oils may also serve as distributing agents during the process of dissemination and concentration of uranium. If greater concentrations of uranium occur in the bitumen than in the enclosing shales, as the limited data suggest, it is entirely reasonable that uranium is carried along with crude oil as it migrates to points of accumulation in the reservoir rocks. Tomkeieff $(1946)^{1}$ quotes data to show that petroleum, on an average, contains 100 grams of uranium per ton, and that oil waters contain

${ }^{1}$ Tomkeieff, S. I., The geochemistry of uranium: Sci. Progress, vol. 34 , no. 136, pp. 696-712, 1946.
10 grams per ton. Highly uraniferous asphaltic sandstones are present in some breached anticlinal struc tures, as for example the San Rafael Swell and the Waterpocket fold in Utah. Evidently hydrocarbons migrated into the closed structures, and, after removal of the cap rock by erosion, all the petroleum except the residual asphalt escaped. The presence of such highly uraniferous asphalts in former structural traps raises several questions. Was the uranium picked up in the path of the migrating hydrocarbons? Was it removed from organic shales from which the petroleum was presumably derived, or were small quantities of uranium inherent in the liquid hydrocarbons concentrated by some process of fractionation of the oil?

The presence of relatively large quantities of radium and radon in some oil and gas fields indicates a possible genetic relationship between the products or uranium and hydrocarbons.

Some of the many problems that are deserving of further investigations, therefore, are (1) the possible migration of uranium in hydrocarbon solutions derived from carbonaceous shales; (2) the possibility of precipitation of uranium compounds from oil solutions; and (3) the effect of polymerization of the hydrocarbons by alpha radiation.

In conclusion, uranium is associated with some coals and carbonaceous marine shales, phosphatic rocks, petroleum products, and disseminated carbonized wood fragments throughout the world. 